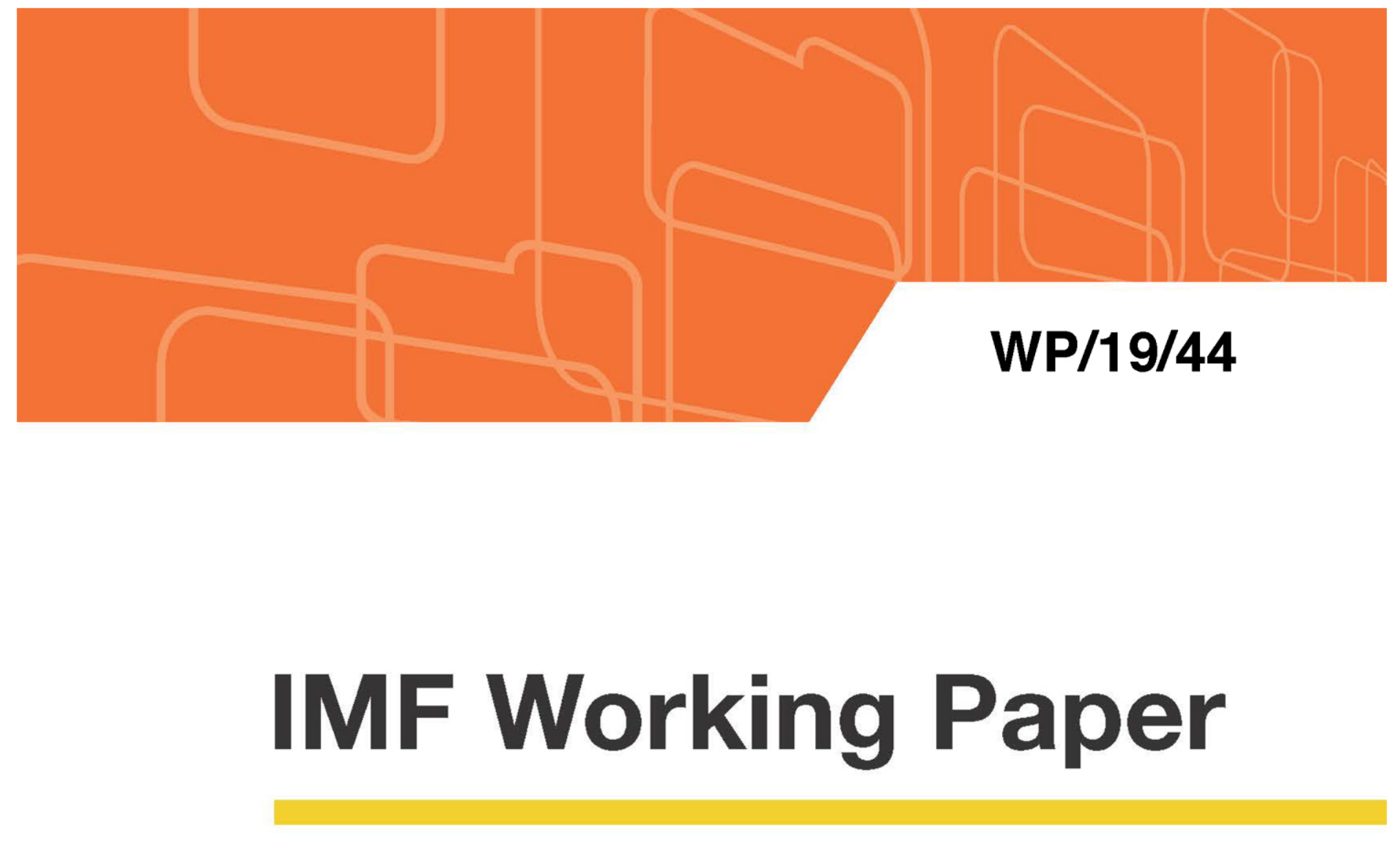

\title{
Negative Monetary Policy Rates and Portfolio Rebalancing: Evidence from Credit Register Data
}

by Margherita Bottero, Camelia Minoiu, José-Luis Peydro, Andrea Polo, Andrea F. Presbitero and Enrico Sette

IMF Working Papers describe research in progress by the author(s) and are published to elicit comments and to encourage debate. The views expressed in IMF Working Papers are those of the author(s) and do not necessarily represent the views of the IMF, its Executive Board, or IMF management.

$$
\text { I N T E R N A T I O N A L M O N E T A R Y F U N D }
$$




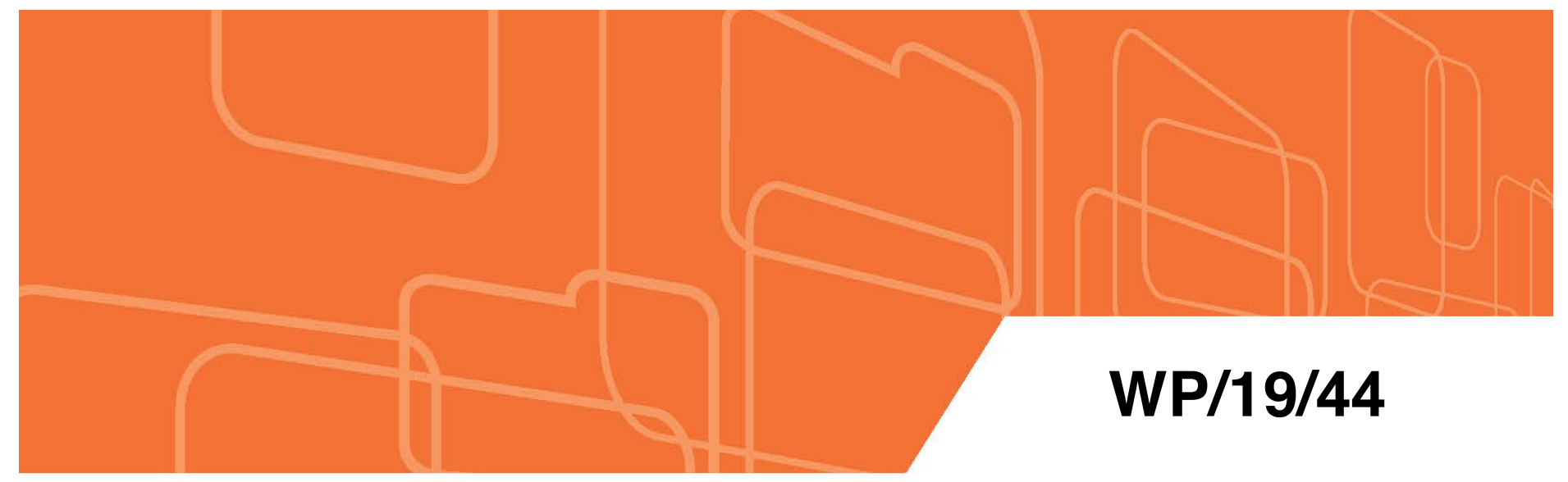

\section{IMF Working Paper}

\section{Negative Monetary Policy Rates and Portfolio Rebalancing: Evidence from Credit Register Data}

by Margherita Bottero, Camelia Minoiu, José-Luis Peydro, Andrea Polo, Andrea F. Presbitero and Enrico Sette

IMF Working Papers describe research in progress by the author(s) and are published to elicit comments and to encourage debate. The views expressed in IMF Working Papers are those of the author(s) and do not necessarily represent the views of the IMF, its Executive Board, or IMF management.

$$
\text { I N T E R N A T I O N A L M O N E T A R Y F U N D }
$$




\title{
IMF Working Paper
}

Research Department

\section{Negative Monetary Policy Rates and Portfolio Rebalancing: Evidence from Credit Register Data ${ }^{1}$}

\section{Prepared by Margherita Bottero, Camelia Minoiu, José-Luis Peydro, Andrea Polo, Andrea F. Presbitero and Enrico Sette}

Authorized for distribution by Maria Soledad Martinez Peria

February 2019

IMF Working Papers describe research in progress by the author(s) and are published to elicit comments and to encourage debate. The views expressed in IMF Working Papers are those of the author(s) and do not necessarily represent the views of the IMF, its Executive Board, or IMF management.

\begin{abstract}
We study negative interest rate policy (NIRP) exploiting ECB's NIRP introduction and administrative data from Italy, severely hit by the Eurozone crisis. NIRP has expansionary effects on credit supply--and hence the real economy---through a portfolio rebalancing channel. NIRP affects banks with higher ex-ante net short-term interbank positions or, more broadly, more liquid balance-sheets, not with higher retail deposits. NIRP-affected banks rebalance their portfolios from liquid assets to credit - especially to riskier and smaller firms - and cut loan rates, inducing sizable real effects. By shifting the entire yield curve downwards, NIRP differs from rate cuts just above the ZLB.
\end{abstract}

JEL Classification Numbers: E52, E58, G01, G21, G28

Keywords: Negative interest rates, portfolio rebalancing, bank lending channel, liquidity management, Eurozone crisis

Authors’ E-Mail Addresses: margherita.bottero@bancaditalia.it, camelia.minoiu@frb.gov, jose.peydro@gmail.com, andrea.polo@,gmail.com, apresbitero@,imf.org, enrico.sette@,bancaditalia.it

\footnotetext{
${ }^{1}$ The views expressed herein are those of the authors and should not be attributed to the Bank of Italy, Board of Governors of the Federal Reserve System, or anyone else associated with the Federal Reserve System, the International Monetary Fund, their Executive Boards, or their management.
} 


\section{Contents}

1 Introduction $\quad \underline{3}$

2 Institutional Background $\quad \underline{11}$

3 Data and Empirical Hypotheses $\underline{14}$

3.1 The Credit Register and other Datasets . . . . . . . . . . . . . 14

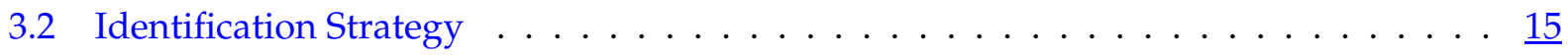

3.2.1 Portfolio Rebalancing vs. Retail Deposits Channel . . . . . . . . . . . . . . . $\underline{15}$

3.2.2 Portfolio Rebalancing Channel and Bank Exposure Variables . . . . . . . . . . $\underline{16}$

3.2.3 Portfolio Rebalancing Channel and the ZLB . . . . . . . . . . . . 17

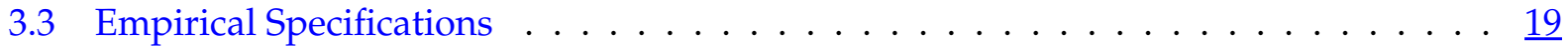

4 Credit Supply $\quad \underline{21}$

4.1 Main Results . . . . . . . . . . . . . . . . . . . . . . . . 21

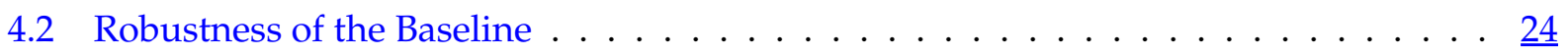

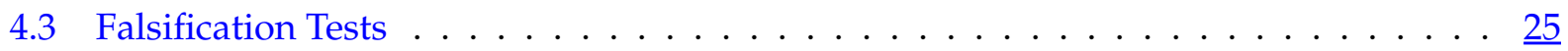

4.4 Heterogeneity: Firm Risk and Size . . . . . . . . . . . . . . . . 27

4.5 Transmission to Lending Rates . . . . . . . . . . . . . . . . . . 28

5 Real Effects $\quad \underline{29}$

6 Conclusions $\quad \underline{30}$

A Online Appendix-Not for publication $\quad \underline{50}$ 
"Negative [policy] rates were introduced for one specific reason: when interest rates reached the zero lower bound, the expectations for the future rates in the long term are only that the rates can go up. So with negative rates we were successful in taking these expectations down"

"By and large our negative interest-rate policies have been a success. [...] We haven't seen bank profitability going down; in fact it is going up."

Mario Draghi $(2016,2017)$, President of the European Central Bank ${ }^{1}$

\section{Introduction}

Negative nominal interest rates are a significant innovation in monetary policy-making, with important implications for finance and macroeconomics. Long thought as unrealistic, negative interest rate policy (NIRP) was introduced in several advanced economies through the banking sector. The first central bank to pay negative rates on bank deposits was the Danish National Bank in 2012, followed by the European Central Bank (ECB), the Swiss National Bank, the Sveriges Riksbank, and the Bank of Japan. NIRP may become even more important in the future given that current interest rates are low and central banks may need room to cut interest rates. ${ }^{2}$ Moreover, from a theoretical point of view, the effects of NIRP on the economy is a priori unclear. While negative rates may expand aggregate demand by removing the zero lower bound (ZLB) (Bernanke, 2017; Rogoff, 2016, 2017), they could also be contractionary for bank lending (Brunnermeier and Koby, 2018). Despite the importance of NIRP for our broader understanding of finance and macroeconomics, compared to other unconventional policies, systematic evidence on the transmission of this policy to the economy through the banking system remains scarce.

The introduction of NIRP as an unconventional tool of monetary policy raises two major questions. First, what is the impact of this policy on credit supply and the real economy? Second, do negative monetary policy rates differ in their transmission to the economy from conventional interest rate cuts just above the ZLB, and from other unconventional monetary policies, such as forward guidance and quantitative easing (QE)? In this paper, we answer these questions by exploiting both the ECB's introduction of negative nominal policy rates in mid-2014 and the Italian administrative credit register, matched with firm- and bank-level balance sheets data.

\footnotetext{
${ }^{1}$ See also https://www.wsj.com/articles/draghi-says-ecbs-negative-rates-have-been-a-success-1507824716, and https:/ / piie.com/events/rethinking-macroeconomic-policy.

${ }^{2}$ Since 1970 policy rates have been cut by more than 500 basis points in response to recessions in the U.S. and the euro area (Eggertsson et al., 2019). At the time of writing, commentators note substantial downside risks across both sides of the Atlantic. For example, Vanguard investment chief sees "near 50-50 chance of U.S. recession in 2020" in the U.S. (https: / / www.reuters.com/article/us-vanguard-markets/vanguard-investment-chief-sees-near-50-50-chance-ofrecession-in-2020-idUSKCN1Q01NL) and, in the euro area, Germany experienced two quarters of no growth in 2018.
} 
We start by documenting an increase in the growth rate of total bank credit after the introduction of NIRP using aggregate time-series data. A loan-level analysis shows that NIRP works through a portfolio rebalancing channel, inducing banks to rebalance their portfolios from liquid assets to credit. NIRP affects banks with higher ex-ante net short-term interbank positions or, more broadly, more liquid balance-sheets. We show that more NIRP-affected banks expand credit supply, especially to ex-ante riskier and smaller firms (without ex-post increasing NPLs), and cut loan rates, inducing sizable firm-level real effects. Our evidence is inconsistent with the view that banks that rely more on retail deposits reduce credit supply in response to negative rates; instead, we show that banks preserve profitability by raising fees on bank deposits. Finally, the announcement of NIRP shifted the entire yield curve (on riskless assets) downwards, thereby widening the spread between the yields of safer, liquid assets and riskier, more illiquid assets; by contrast, previous policy rate cuts in positive territory close to the ZLB and forward guidance announcements were unable to flatten the yield curve and did not cause a similar rebalancing of bank portfolios.

Our analysis innovates on existing studies in major ways. First, we show different resultsconsistent with a portfolio rebalancing channel, but not with a retail deposits one-and argue (whether and why) the effects of NIRP on bank asset allocations are different from those of other policy rate cuts just above the ZLB or other unconventional policies (including QE, where there are similar results for broad liquid assets but not for short-term interbank positions). Our results inform macro models on the transmission of NIRP to the real economy via the bank lending channel by providing estimates of the elasticity of credit to balance sheet variables that proxy for different transmission channels of NIRP. Second, our context provides an excellent setting for empirical identification that is also well fit for testing theoretical predictions and policy analysis. Italy has high quality administrative micro data that are necessary for identification of credit supply, real effects and heterogeneous effects across firms. Moreover, in the euro area and Japan, NIRP was adopted during adverse economic conditions to avoid recession and deflation, unlike in Switzerland and Denmark, where it was introduced to limit strong capital inflows and exchange rate appreciation. Before NIRP, monetary conditions had been tighter in Italy than in several other European countries. In Italy, GDP growth was negative in both 2012 and 2013 (also suffering from the euro area sovereign debt crisis); at the same time the ECB balance sheet was decreasing, opposite to the Fed and Bank of England ones. Finally, the literature on unconventional monetary policy has concentrated on QE, Long Term Refinancing Operations (LTRO) and forward guidance, despite the fact that negative rates are unique and a number of core economies have adopted them. 
Macroeconomic theory suggests that a cut in policy rates expands aggregate demand (thereby boosting economic growth and prices), hence it finds in the ZLB an important constraint (Bernanke, 2017; Rogoff, 2016, 2017; Dell'Ariccia et al., 2018). As shown in the opening quotes, Draghi (2017) argues that NIRP has had positive effects. However, other central banks, including the U.S. Federal Reserve and the Bank of England, have been less keen to adopt this policy (Bernanke, 2016). ${ }^{3}$ Moreover, Brunnermeier and Koby (2018) theoretically show that there may be a "reversal" interest rate at which lower rates undo the cut's intended effects on bank lending and become contractionary. This reversal rate is a low interest rate, potentially even negative. Very low monetary rates are also believed to drive reach-for-yield behavior by financial intermediaries (Rajan, 2005; Taylor, 2009; Allen and Rogoff, 2011; Stein, 2013; Martinez-Miera and Repullo, 2017), consistent with a risk-taking channel of monetary policy (Adrian and Shin, 2011; Borio and Zhu, 2012).

NIRP can affect the real economy via the banking system primarily through two channels. A first channel of transmission hinges on the pass-through of negative policy rates to bank retail deposit rates ("retail deposits channel"). Given that in practice retail deposit rates are sticky at zero, NIRP may reduce banks' net interest margins and profits, eroding their capital. This phenomenon should be more pronounced for banks that are more dependent on retail deposits, leading them to cut credit supply and even to increase risk-taking (Heider et al., 2019) or/and to weaken the pass-through to loan rates (Eggertsson et al., 2019) as compared to other banks. However, banks with large retail deposits may try to simultaneously offset the effects of NIRP by charging higher service fees (Altavilla et al., 2018; IMF, 2016; Lopez et al., 2018).

An alternative transmission channel works through banks' safer, liquid assets and portfolio rebalancing. Negative interest rates penalize the holding of liquid, safer assets, incentivizing banks to rebalance their portfolios from low- or negative-yield liquid assets towards higher-yield assets, such as corporate loans (a "portfolio rebalancing channel", see e.g., Bernanke (2016); Rostagno et al. (2016)). ${ }^{4}$ In the words of Brunnermeier and Koby (2018): "as yields on safe assets decrease, banks decrease their lending rates for risky loans in order to substitute their safe assets positions into riskier high-

\footnotetext{
${ }^{3}$ Bernanke (2016) on the views of the Federal Reserve's decision body (Federal Open Market Committee, FOMC) and the Bank of England regarding NIRP: "Interestingly, some advocates of a higher inflation target have been dismissive of the use of negative short-term interest rates, an alternative means of increasing "space" for monetary easing [...] Williams said: "Negative rates are still at the bottom of the stack in terms of net effectiveness." Williams's colleague on the FOMC, Eric Rosengren, has suggested that [...] negative rates should be viewed as a last resort. My sense is that Williams's and Rosengren's negative view of negative rates is broadly shared on the FOMC. Outside the United States, Mark Carney, governor of the Bank of England [...] has indicated he was "not a fan" of negative interest rates."

${ }^{4}$ In our data, the difference in yields, before NIRP, between liquid assets and corporate loans is about 10 percentage points.
} 
yield ones, another effect which the central bank seeks to induce". This would be especially the case if NIRP moves the entire yield curve downward-after breaking through the ZLB, market participants may expect rates to stay low or negative for long (see Draghi (2016)'s initial quote). The fall in the yield of safer assets of all maturities would widen a wedge between safer, more liquid and riskier (illiquid) assets thus incentivizing banks to rebalance their portfolio to preserve profitability. According to this logic, a policy rate cut into negative territory would work differently from regular policy rate cuts (within the positive territory) in the proximity of the ZLB, but would work similarly to quantitative easing (QE) given the accompanying flattening of the yield curve (see, e.g. Gambetti and Musso (2017); Altavilla et al. (2015) for the Euro area, D`Amico and King (2013) for the U.S.) and increase in the safety premium (see Krishnamurthy and Vissing-Jorgensen (2011) for evidence in the U.S.).

Italy provides an ideal set-up for the analysis of NIRP as it is a large European economy in which the banking sector provides the bulk of firm financing and was severely hit by the euro area sovereign debt crisis. As part of a monetary union, Italy is additionally well-suited as a case study because Italian banks are affected by the monetary policies of the ECB for the entire euro area. Most commentators note that unconventional monetary policies in the euro area arrived later compared to the U.S. and the U.K. In particular, NIRP was implemented in mid-2014 and large scale asset purchases (LSAP) only in 2015. As of 2013-14, before NIRP, ECB's balance sheetopposite to the Federal Reserve and Bank of England ones-was decreasing, though GDP growth was lower in the euro area than in the U.S. and the U.K. By then, economic conditions in Italy had been worse than in the rest of the euro area since some time. This supports the view that the ECB's monetary policy was not directly tackling the Italian situation but rather reacting to the slowdown in economic recovery that was starting to depress inflation expectations, with the goal of maintaining price stability of the area as a whole.

Furthermore, Italy offers a significant data advantage for the study of monetary policy transmission through its comprehensive administrative micro datasets. We use the credit register of the Bank of Italy, which offers detailed information on bank loans to all Italian firms, and from which we compute outstanding loan amounts and lending rates at the firm-bank-month level. ${ }^{5}$ We further double-match this dataset with detailed firm and bank balance sheet information to study the effects of NIRP on both firms and banks that are connected through borrowing relationships. Data on bank balance sheets come from supervisory reports while data on firm financials are obtained

\footnotetext{
${ }^{5}$ This is a major data advantage as loan rates are absent in most the credit registers around the world.
} 
from the official balance sheet data deposited by firms to the Chambers of Commerce, as required by the Italian law. These administrative datasets allow us to conduct a comprehensive analysis of bank asset allocations and their spillovers to the real economy when policy rates turn negative.

Our empirical approach exploits cross-sectional variation in ex-ante bank exposure to NIRP using a difference-in-differences setting. Thanks to the granularity of our data, in our lending regressions we include firm fixed effects which allow us to identify the supply of credit by banks as we keep constant firm-level credit demand and other firm fundamentals (Khwaja and Mian, 2008). This approach is crucial in our setting as monetary policy impacts both the supply and demand of credit through the bank lending and the firm borrowing channels. To identify the portfolio rebalancing channel we focus on two bank-level exposure variables: the net interbank position and the liquid balance sheet position. (1) Banks' interbank position, a narrower measure of exposure to NIRP, is defined in net terms and is computed as interbank loans minus interbank deposits with maturity of up to one week (measured on the closest date before the announcement of negative policy rates, in March 2014), divided by total assets. We adopt this measure because interest rates on interbank loans and deposits up to one week were the most affected by NIRP and even became negative soon after the introduction of the policy. Also, note that interbank activity is large (Upper, 2006). (2) Banks' liquid balance sheet position is defined as the ratio of securities over assets and is common in the literature on the bank lending channel of monetary policy (e.g., Kashyap and Stein, 2000; Jiménez et al., 2012). It is a broader measure (in terms of asset size, types, and maturities that it captures) of exposure to NIRP (for Italian banks, securities account for 29\% of total assets). We adopt this measure also because the change of the yield curve induced by NIRP affected all maturities. ${ }^{6}$

We now describe the main results in more detail. Analyzing the time series, the growth rate of total bank credit increases after the introduction of NIRP. In addition, banks with larger ex-ante net interbank position cut interbank loans after the introduction of negative policy rates. Similarly, banks with higher liquidity reduce the share of liquid assets in their portfolio after the introduction of NIRP. Using data from the credit register, we find that NIRP-affected banks (i.e., those with larger ex-ante net interbank position or more liquid balance sheet) also increase their supply of

\footnotetext{
${ }^{6}$ Our results are robust to controlling for a measure of (both realized and unrealized) windfall gains from the repricing of securities due to the NIRP announcement. Additionally, our estimates of the impact of NIRP are different from those when policy rate cuts are within positive territory in our data (despite that there are also windfall gains) and, more generally, compared to results for the U.S. (e.g., Kashyap and Stein, 2000) or Spanish data (e.g., Jiménez et al., 2012).
} 
corporate loans more than other banks during the same period. This effect is present as early as 1 month after the implementation of the policy and persists for at least 12 months. Moreover, we find parallel pre-trends before the policy announcement. These results lend support to the presence of a portfolio rebalancing channel.

Notably, we find no systematic evidence of a retail deposits channel: the supply of credit by banks with larger retail deposits does not change (and in fact, in some regressions it increases, opposite to the predictions of the retail deposit channel, although this result is not robust); we also show that banks with larger retail deposits increase fees for banking services related to the holdings of deposits after NIRP, thus offsetting any compression in deposit margins.

NIRP-affected banks further rebalance their assets by taking more risk in their loan portfolios: the relative increase in loan supply is stronger vis-a-vis ex-ante smaller and riskier firms (where firm risk is measured by credit ratings). We find no evidence that this increase in ex-ante risk-taking translates into higher ex-post non-performing loans (NPLs) subsequently. Therefore, greater risk-taking is consistent with higher credit supply to ex-ante more constrained but viable firms. We also show that NIRP-affected banks reduce the interest rates they charge to loans to corporate borrowers: a change in one standard deviation in the banks' net interbank position (liquidity) leads to $6.9 \%(4.4 \%)$ reduction of lending rates. Hence the increase in credit supply is both in terms of higher volumes and lower prices.

The increase in credit supply by NIRP-affected banks leads to sizable firm-level real effects. A one standard deviation increase in banks' net interbank position (liquidity) is associated with a 2.8 (1.4) percentage point increase in total credit. In addition, more bank credit translates into stronger firm performance, as firms borrowing ex-ante more from lenders with greater exposure to NIRP expand economic activity. A one standard deviation increase in banks' net interbank position (liquidity) is associated with an increase in firms' investments by 5.6 (5.2) percentage points.

Taken together, our results suggest that banks which are relatively more affected by negative interest rates rebalance their portfolios from lower yield assets (such as short-term interbank claims or, more broadly, liquid holdings) towards higher yield assets (such as corporate loans in general, and loans to ex-ante riskier and smaller firms in particular). This response is inconsistent with excessive-risk taking behavior as there is no ex-post increase in NPLs for more affected banks. Instead, greater credit supply leads to an improvement in the financing conditions of firms, which in turn are better able to expand their activities, with beneficial effects for the real economy.

Falsification tests show that our results are not driven by systematic differences across banks 
in their lending to firms with specific characteristics nor by prior trends in loan growth. Our results survive a large battery of robustness tests, including controlling for other unconventional monetary policies, such as the Targeted Longer-Term Refinancing Operations (TLTRO), which were implemented a few months after NIRP. Moreover, our results hold in a narrowly defined time window, which minimizes the potential effect of confounding policies.

Finally, our analysis suggests that NIRP works differently from conventional monetary policy. The standard bank lending channel posits that monetary easing has a greater impact on credit supply for banks with lower liquid-to-total assets ratios (Kashyap and Stein, 1995, 2000; Jiménez et al., 2012). By contrast, our results show that an interest rate cut into negative territory has stronger effects for banks with larger liquid-to-total assets ratios. Further, our results are also not present after previous rate cuts just above the ZLB or after previous forward guidance announcements. The introduction of NIRP steered market expectations by removing the ZLB, inducing a downward shift and a simultaneous flattening of the entire yield curve (e.g., Draghi, 2016; Cœuré, 2017; Grisse et al., 2017), which previous rate cuts above the ZLB (or forward guidance announcements) were unable to achieve (see Figure 3). The fall in the yield of safer, liquid assets of all maturities widened a wedge between the yields of safer and riskier assets, thus incentivizing banks to rebalance their portfolios. ECB's January 2015 announcement of QE policies is also associated with a strong flattening of the yield curve and, in fact, we find similar rebalancing effects for that event. However, around the QE announcement we find that the estimated coefficient of bank liquidity is similar to the NIRP coefficient, while the coefficient of net interbank position becomes smaller and loses statistical significance. This is not surprising given that both QE and NIRP announcements flattened the yield curve, but the two policies differ in so far as NIRP was also associated with a drop in short-term rates, which penalizes holdings of short-term interbank claims even more than QE.

Contribution to the literature. Our results are important to inform macro models on the transmission of NIRP to the real economy via the bank lending channel, in the spirit of Nakamura and Steinsson (2018). We provide estimates of the elasticity of credit to balance sheet variables that proxy for different transmission channels of NIRP to lending. Our results support macro models of the transmission of NIRP based on portfolio rebalancing rather than based on an impact of profitability, or more generally, models featuring both channels that show in calibrations a prevalence of portfolio rebalancing, and thus an expansionary effect of NIRP on lending (and thereby on the 
real economy).

Our analysis is closely related to several studies of the impact of NIRP on bank lending. Heider et al. (2019) examine the effects of negative rates from June 2014 on syndicated lending activity in the euro area. Based on a difference-in-differences estimation that exploits variation in banks' reliance on retail deposits as a measure of exposure to NIRP, the authors show that banks with more retail deposits (hence more constrained in passing negative rates to depositors) reduce corporate loan growth and take more risk than other banks. In our analysis, based on more granular and comprehensive data from a country with a large presence of bank-dependent small and medium-sized firms, the retail deposits channel is inactive. In addition, we show that NIRP has expansionary effects on credit supply (consistent with Draghi (2016)'s initial quote) and, in turn on the real economy, through a portfolio rebalancing channel. Eggertsson et al. (2019) examine the effects of NIRP through the retail deposits channel. Using bank-level data and variation in the share of deposit funding across Swedish banks, the authors document a weakening pass-through from the policy rate to loan rates during the NIRP period. By contrast, we use loan-level data and document a strong pass-through from negative policy rates to loan rates while controlling for shifts in unobserved time-varying firm characteristics, including firm-level credit demand.

Basten and Mariathasan (2018) similarly use bank-level data to document the experience of Swiss banks using excess reserves at the central bank as a measure of sensitivity to negative policy rates. In a difference-in-differences framework, they find that bank profitability is unaffected by NIRP as banks offset lower-interest margins with higher fees, but they tend to take more risk. In addition to different results and to the fact that they use bank-level data, which cannot control for firm-level credit demand and risk, another important element that differentiates our analysis is the macroeconomic environment. We examine a pure monetary policy decision in a country facing depressed aggregate demand and a crisis (where the theoretical literature argues that lower rates are needed to boost economic activity), while Basten and Mariathasan (2018) examine a policy decision aimed at mitigating currency appreciation in a safe-haven country facing strong capital inflows. Compared to this paper, we additionally show why NIRP is special compared to previous rate cuts in the proximity of the ZLB and to other unconventional monetary policies, and document its real effects. ${ }^{7}$

\footnotetext{
${ }^{7}$ Similar to Basten and Mariathasan (2018), Demiralp et al. (2017) analyze excess reserves and NIRP using bank-level data. In Italy, excess reserves are close to zero. Arseneau (2017) uses supervisory data from the U.S. bank stress tests, in which U.S. banks are asked about the balance sheet impact of hypothetical NIRP. Arseneau (2017) finds that U.S. banks vary significantly in their exposure to negative rates and the effect of NIRP on bank margins would depend on their
} 
Our paper further contributes to the broader literature on unconventional monetary policy, which focuses on more common policies such as large-scale asset purchases, large liquidity injections and forward guidance (see, among others, Bhattarai and Neely (2016); Chakraborty et al. (2016); and Rodnyansky and Darmouni (2017) for U.S. policies; and Acharya et al. (2016); Acharya et al. (2019) and Peydró et al. (2017) for European policies). ${ }^{8}$ Our paper also adds to the literature on the risk-taking channel of monetary policy (Adrian and Shin, 2011; Jiménez et al., 2014; Dell'Ariccia et al., 2017, among others). Our main contribution to these two strands of literature is to focus on the portfolio rebalancing channel, bank credit supply, and associated real effects of negative interest rates.

The remainder of the paper is organized as follows. Section 2 discusses the negative interest rate policy of the ECB. Section 3 describes the data, hypotheses, and empirical approach. Sections 4 and 5 document the effects of NIRP on credit supply and firm-level outcomes. Section 6 concludes.

\section{Institutional Background}

In this section we discuss the institutional context in which the ECB introduced NIRP and the details of its implementation and, by doing so, we lay out the key elements of our empirical strategy.

Before NIRP, the monetary transmission mechanism was impaired, as lower policy rates were not transmitted to rates on loans to firms and households (Hartmann and Smets, 2018). As a result, monetary conditions in the euro area were tighter than in the U.S. or the U.K., despite the relatively weaker state of the economy. At that time, GDP growth and inflation were lower in the euro area than in the U.S. and the U.K., but the ECB's balance sheet was decreasing, in contrast to the growing balance sheets of the Federal Reserve and Bank of England. Importantly, economic conditions in Italy were worse condition than in the euro area. The Italian economy was characterized by economic slack and low inflation (well below the $2 \%$ target), and it was strongly

liquidity provision. None of these previous studies use micro data on lenders and borrowers so they cannot control for unobserved time-varying firm-level characteristics such as credit demand and risk. Finally, Arce et al. (2018) compare the lending behavior of Spanish banks that reported to the ECB's Bank Lending Survey their views on the incidence of NIRP on net interest income in April 2016 (that is, two years after the introduction of NIRP). Their analysis shows that the banks which indicated profitability had been negatively impacted by this policy took less risk in their loan portfolio and that credit supply did not change differentially across banks. Compared to the approach of this paper, our measures of bank exposure to NIRP are computed prior to the policy (not ex-post), they are grounded in a specific transmission channel of monetary policy (namely, through a portfolio rebalancing channel), and they rely on supervisory data as opposed to being self-reported.

${ }^{8}$ For the theoretical literature on unconventional monetary policy see Gertler and Karadi (2011), Curdia and Woodford (2011) and McKay et al. (2016), among others. 
affected by the euro area sovereign debt crisis. ${ }^{9}$

Since 2012 a number of major central banks around the world pushed key short-term policy rates into negative territory in an effort to either further ease monetary conditions and to support economic activity or to limit capital inflows and the associated exchange rate appreciation. ${ }^{10}$ To date, monetary rates are negative in countries accounting for $25 \%$ of world GDP, and the amount of debt globally trading at negative interest rates is USD 8 trillion. ${ }^{11}$ On June 11,2014 , the ECB reduced the rate it pays on overnight deposits with the central bank in excess of reserve requirement ("excess reserves") to $-0.10 \%{ }^{12}$ The rationale behind this rate cut was to further ease monetary conditions by pushing down yields and borrowing costs and to encourage banks to invest in alternative assets, boosting their prices. In the words of Hutchinson and Smets (2017, p. c3), “the rationale of this measure was that by extending the scope of conventional monetary policy beyond the ZLB, the entire distribution of short-term rates was shifted downwards and additional stimulus could be provided to the economy." The ECB implemented further rate cuts in its deposit facility rate to $-0.20 \%$ on September 10,2014 , to $-0.30 \%$ on December 9,2015 , and finally to $-0.40 \%$ on March 16 , 2016, where it has remained ever since. ${ }^{13}$

Following the initial decline of the deposit facility interest rate to negative levels in June 2014, short-term interbank rates immediately dropped. The Euro OverNight Index Average (EONIA), a measure of the cost of funds on the Eurozone overnight interbank market, turned negative for the first time in August 2014. Between the end of April 2014 and the end of June 2014, the one-week Euro Interbank Offered Rate (EURIBOR) went down by 20 basis points (bps), became negative later on as well, and remained below zero for the entire NIRP period in our analysis (see Figure 1). Around the NIRP announcement the drop in the interbank rates at one-month and three-

\footnotetext{
${ }^{9}$ According to the IMF's World Economic Outlook data (October 2018 vintage), real GDP growth in 2013 was $2 \%$ in the U.K., $1.8 \%$ in the U.S., $-0.2 \%$ in the euro area and $-1.7 \%$ in Italy.

${ }^{10}$ The financial media (WSJ, FT) and economics blogs have widely covered the topic of negative interest rates.

${ }^{11}$ Source: Bloomberg (December 18, 2018).

${ }^{12}$ Euro area banks are required to hold a certain amount of funds as reserves in their current accounts at their national central bank (minimum reserve requirement), which are remunerated at the main refinancing operation (MRO) rate. Further, they can hold reserves in excess to the minimum reserve requirement either in the Eurosystem deposit facility or as reserve holdings in their current accounts. Differently from the past, ever since the ECB decided to introduce a negative rate on the deposit facility, it treats the current account balances (in excess of the minimum reserve requirement) and the deposit facility in the same way. Both yield negative rates.

${ }^{13}$ In the press releases that announced subsequent cuts in the deposit facility, the ECB simultaneously announced several extensions of the QE program. For instance, on December 3, 2015, the ECB extended the length of QE program by 6 months (the 60 billion euro monthly purchases were to run until March 2017 instead of September 2016). On March 10,2016 , the ECB also announced an increase from 60 to 80 billion euro in the monthly purchases and also an extension of eligible assets to include investment-grade euro denominated bonds issued by non-bank corporations (Corporate Sector Purchase Programme). These simultaneous QE-related announcements make these subsequent additional ratecut events less suitable for the identification of NIRP impact.
} 
month maturities was smaller (respectively, 17 and $14 \mathrm{bps}$ ). Both one-month and three-month rates remained positive throughout the period.

The announcement of NIRP also impacted the medium and long end of the yield curve. In fact, the entire yield curve shifted downward and flattened (see Figure 3). The fall in the yield of safer assets across all maturities widened the wedge between the yields of safer, more liquid assets compared to those of riskier, more illiquid assets (we discuss these development in more detail in Section 3.2.)

In May 2014, the growth rate of bank credit to non-financial corporations in Italy was negative, at $-4.7 \%$ on a yearly basis, in an environment of depressed aggregate demand. As shown in Figure 2, immediately after the introduction of NIRP, credit growth picked up, reaching $-3.1 \%$ at the end of June 2014. While still negative, it continued to rise, reaching $-2.3 \%$ in December 2014. Besides reflecting demand dynamics, that we will control for more thoroughly in the analysis, these developments may also benefit from other monetary policies that the ECB implemented during the period. Notably, on June 5, 2014 the ECB announced its TLTRO program, which was implemented starting in September 2014. The program aimed at boosting bank credit by offering long-term funding to Eurozone banks on attractive terms. If the TLTRO had an expansionary effect on the economy before its implementation and if banks' take-up of TLTRO funds was correlated with their March 2014 net interbank and liquidity positions, we may incorrectly attribute our estimated effects to the NIRP instead of this other policy. Although we control for the potentially confounding effect of the TLTRO with a bank-level measure of ex-ante capacity to borrow under the TLTRO (based on the supervisory data), it is also important to highlight that Benetton and Fantino (2018) show that the TLTRO did indeed reduce the costs of credit for Italian firms but only after the implementation of the second round of the policy, namely only in the second and third quarter of 2015 (and hence outside our baseline time window). (We discuss the policy in more detail and show our main results are robust to controlling for this policy in Section 4.1.)

Furthermore, a few months later, on January 22, 2015, the ECB announced the first large scale asset purchase (LSAP) by expanding its limited Asset Purchase Program (APP). This policy action was considered as the start of the ECB's QE, with the objective of providing additional monetary policy stimulus and further easing borrowing conditions of households and firms. The implementation started on March 9, 2015. Both the announcement and the implementation of this program are largely outside the time window of our baseline results so we can comfortably assume that the APP is not affecting our estimates. With the announcement of January 22, 2015, the ECB ex- 
panded its existing, very limited (quantitatively speaking) asset-purchase programs (of covered bonds and asset-backed securities) to include public-sector bonds for a total of 60 billion euros of monthly purchases. ${ }^{14}$ We also analyze the effects of this LSAP QE policy (and those of previous conventional and unconvential monetary policies) and compare them with NIRP, in order to understand whether-and why-NIRP is special.

\section{Data and Empirical Hypotheses}

\subsection{The Credit Register and other Datasets}

We employ a double-matched administrative bank-firm monthly panel dataset covering the lending activities of Italian banks between 2013 and 2015. The dataset draws on three sources: (i) the loan-level credit register of the Bank of Italy, which reports outstanding loan exposures (with minimum size of 30,000 euros) of all banks operating in Italy vis-a-vis Italian non-financial firms; (ii) supervisory data on bank balance sheets; and (iii) data on firm financials from the proprietary CADS database, owned by Cerved Group, which is a member of the European Committee of Central Balance-Sheet Data Offices and collects official balance sheet data deposited by firms to the Chambers of Commerce, as required by the Italian law. All data are monthly, with the exception of firm financials which are yearly and selected bank balance sheet variables which are quarterly (such as capital and net interbank position) or semiannually (income from fees).

Given the relatively small loan size threshold for inclusion of loans in the credit register, its coverage is almost universal, comprising all firms with bank relationships. We drop foreign bank branches and subsidiaries (as their liquidity depends on foreign headquarters) and cooperative or mutual banks (as they are subject to different regulations). Our final regression sample contains more than 167,000 firms with multiple banking relationships, borrowing from 95 banks. Loan exposures refer to credit lines, short-term loans (with maturity shorter than one year), and longterm loans.

Data on loan Interest rates are from a special section of the Credit Register (Taxia) and are reported by a representative sample of the largest banking groups and individual banks operating

\footnotetext{
${ }^{14}$ The initial asset-purchase programs of covered bonds (CBPP3) and asset-backed securities (ABSPP) were announced in September 2014 and implemented, respectively, in October and November 2014. The extent of these initial purchases was so limited quantitatively that only the announcement of January 2015 is considered to be the start of the ECB QE programme, also called LSAP (see, for instance, Altavilla et al. (2015) or Gambetti and Musso (2017)). However, in Section 4.1 we show that our results are robust also if we consider a very short window of only one month around the NIRP announcement.
} 
in the country (covering more than $80 \%$ of total bank lending in Italy). ${ }^{15}$ For a robustness test, we also use data from the securities register at the Bank of Italy, with information on the holdings of each security held by each bank in each month, coupled with data on securities yields and prices from Thomson Reuters Eikon, to construct a bank-level measure of windfall gains (defined as profits or losses due to the revaluation of the securities in the portfolios).

Italian banks play a key role in financing the real economy, as most borrowers are small and medium-size enterprises with limited access to alternative sources of external financing. Commercial banks have a traditional business model focused on loan intermediation and banking services. Retail deposits (almost entirely from domestic residents) account for $69 \%$ of total funding, wholesale funding for $24 \%$, and Eurosystem financing for the remaining $7 \%$. On the asset side, loans to the non-financial private sector account for $39 \%$ of total assets (with loans to non-financial firms at $60 \%$ of the loan book).

\subsection{Identification Strategy}

\subsubsection{Portfolio Rebalancing vs. Retail Deposits Channel}

In the words of the ECB President Mario Draghi: "negative [policy] rates were introduced for one specific reason: when interest rates reached the zero lower bound, the expectations for the future rates in the long term are only that the rates can go up. So with negative rates we were successful in taking these expectations down" (Draghi, 2016). The introduction of NIRP puts downward pressure on the yields of bank liquid assets and shifts banks' risk-reward calculus for asset allocation, with loans becoming more attractive (Bernanke, 2016; Rostagno et al., 2016).

However, when interest rates become negative, profit margins could shrink if banks do not pass through short-term funding rates to retail deposits (Heider et al., 2019; Eggertsson et al., 2019). Therefore, both a portfolio rebalancing channel and a retail deposits channel may operate simultaneously.

We examine whether Italian banks are able to compensate for the compression of intermediation margins from incomplete pass-through of negative rates to retail deposit rates with higher fees on banking services. As seen in Table A1, banks with greater retail deposits obtain higher in-

\footnotetext{
${ }^{15}$ For each credit relationship with commitments above 75,000 euros, banks report two numbers each quarter: first, the amount paid as interest and second, the amount of the loan outstanding times the days the amount was outstanding. If the outstanding amount is 100,000 euros for 45 days and 150,000 for the remaining 45 days of the quarter, the reported number is $100,000 \times 45+150,000 \times 45$. By dividing the interest payments by the second number we obtain the interest rate paid on the loan, which we annualize (see Sette and Gobbi, 2015).
} 
come from fees and commissions in the months following the introduction of NIRP. Importantly, this correlation is robust to controlling for other bank characteristics. This finding suggests that the retail deposits channel may be ineffective in our context; we directly test this hypothesis in Section 4 .

\subsubsection{Portfolio Rebalancing Channel and Bank Exposure Variables}

To identify the portfolio rebalancing channel we focus on two variables: first, the banks' net interbank position and, second, a broader measure of bank liquidity. Both measures are computed prior to the policy.

The European interbank market is very large and is mainly concentrated in short-term maturities (Upper, 2006). Interest rates in this market were immediately affected by negative monetary policy rates. The one-week Euro Interbank Offered Rate (EURIBOR) experienced the largest drop compared with interbank rates at longer maturities and soon became even negative. Since banks generally act as both lenders and borrowers in the interbank market (Angelini et al., 2011; Acharya and Merrouche, 2012), we measure bank-level exposure to NIRP with the net interbank position, computed as by the ratio of interbank loans minus interbank deposits with maturity up to one week to total assets. This measure includes all loans and deposits with banks, both domestic and foreign, as well as repos. Interbank lending at maturities shorter than one week represents about $70 \%$ of total activities in the interbank market.

We use the net interbank position because rates on interbank market were immediately affected by NIRP and became even negative. In addition, we adopt another measure of bank-level exposure to NIRP, namely the liquid balance sheet position (computed as securities divided by total assets). This measure achieves two purposes. First, it is a broader measure of balance sheet liquidity (in terms of maturities and assets), it is more sizeable, and more commonly used in the literature of the bank lending channel of monetary policy (e.g., Kashyap and Stein, 2000; Jiménez et al., 2012). Second, the downward shift in the yield curve after NIRP applied across all maturities, not only very short-term maturities. ${ }^{16}$ Alternative measures of exposure to NIRP, such as the banks' reserve holdings in excess of the minimum reserve requirement, are of limited use in our context as Italian banks essentially did not hold reserves in excess of the amount required by regulation during the sample period. ${ }^{17}$

\footnotetext{
${ }^{16}$ In our sample, net interbank position and liquidity are weakly negatively correlated. We find similar and consistently robust results if we measure bank-level exposure to NIRP with the sum of these two variables.

${ }^{17}$ Average excess reserves in June 2014 account for $0.001 \%$ of total assets for the typical bank in our sample, with a
} 
We compute the net interbank position and the broader liquidity position as of end-March 2014, the closest available date before the implementation of NIRP (on June 11, 2014). Note that our data on bank-level interbank market position are available on a quarterly basis, while data on market expectations show that NIRP was already somewhat expected in May 2014 (Wu and Xia, 2017). In March 2014 the average net interbank position is positive and accounts for $4 \%$ of assets, while liquidity accounts for $29 \%$ of assets (Table 1). To further rule out potential concerns that banks adjusted their liquidity positions ahead of NIRP, Figure A1 shows that there is strong persistence in bank-level net interbank position and liquidity over time: comparing end-December 2013 and end-March 2014 data shows that banks lie close to the 45 degree line. In addition, Figure A2 shows significant cross-sectional variation in net interbank position and liquidity, both measured at end-March 2014.

Consistent with a portfolio rebalancing channel and corroborating the choice of exposure variables, in multivariate bank-level regressions we find that banks with more liquid assets before NIRP reduce liquid assets in the months following the introduction of NIRP (Table A2). Comparing the net interbank position in March 2014 against the change in the net interbank position in the following 6 months (between March and September 2014) shows that banks with greater ex-ante exposure are more likely to reduce their net position in the short-term interbank market (column 1) and this reduction is driven by a reduction in interbank loans (column 2) rather than an increase in interbank deposits (column 3). Similarly, we find that banks with more liquidity in March 2014 reduce the amount of liquid assets in their balance-sheets between March and September 2014 (column 4). However, if we run the same test in the previous 6 months, i.e. before NIRP introduction, we do not find the same reduction in interbank loans or securities (Table A3).

\subsubsection{Portfolio Rebalancing Channel and the ZLB}

In theory, the portfolio rebalancing channel should operate for any change in monetary policy rates, above or below the ZLB. What is different about this channel during NIRP?

According to Benoît Cœuré, Member of the Executive Board of the ECB, "with short-term policy rates approaching levels closer to zero during the early phases of the most recent easing cycle, this channel had become less effective" (Cœuré, 2017). He goes on to argue that when the ECB changes the key policy rates during normal times, the central bank is able to directly impact the short end of the

highly-skewed distribution (for the vast majority of banks, the share of excess reserves in total assets is negligible). This is not surprising as excess reserves are generally very small in the countries of the periphery of Europe (Baldo et al., 2017). 
yield curve, which is the basis of the expectations component. To the extent that market participants see a change in policy rates as the beginning of an incremental series of changes, longer-term rates adjust accordingly. However, in the years before NIRP, market participants believed negative rates were unrealistic and were therefore not pricing the degree of accommodation they normally would have expected. In other words, when nominal rates approach the ZLB, the transmission of short-term policy rate cuts to long-term rates becomes weaker (Ruge-Murcia, 2006).

In Cœuré (2017) words, the "decision in June 2014 to introduce negative deposit facility rates restored our ability to steer market expectations, [...] by signaling to the market that policy rates could go below zero, we ultimately succeeded in shifting downwards the entire distribution of future expected short-term rates, thereby providing important additional accommodation."18 Figure 3 shows that this was indeed the case. We observe both a downward shift and a flattening of the entire yield curve only after NIRP and not after the previous rate cut in July 2012 (within positive territory) nor in response to the forward guidance announcement in July 2013. Rostagno et al. (2016) conclude that NIRP was able to "rehabilitate monetary policy in the low rate world". By directly flattening the yield curve, negative nominal interest rates reinstated the transmission of monetary policy and facilitated a reallocation of bank assets, with potential benefits for lending and the real economy. This result is clearly visible in Figure 4, which shows that the introduction of NIRP has been able to generate incentives for portfolio reallocation. The fall in the yield of safer assets of all maturities widened a wedge between safer, more liquid assets (such as long-term European government bonds) and riskier assets (such as BB-rated European non-financial corporate bonds). ${ }^{19}$ This is consistent with an increase in the safety premium after QE as documented by Krishnamurthy and Vissing-Jorgensen (2011) for the U.S. In Figure 3 we show that a similar flattening of the yield curve takes place in January 2015 when the ECB announced its first LSAP QE (via the expanded APP). In Section 4.3 (see also Figure 3) we analyze whether and why NIRP is special by testing the effectiveness of the portfolio rebalancing channel after the interest rate cut and the forward guidance announcement made in the months before NIRP, when rates were low but still above the ZLB, and after the QE

\footnotetext{
${ }^{18}$ Lemke and Vladu (2017) show theoretically that this was indeed the case. By pushing down the effective lower bound, negative policy rates enabled current and future rates to be negative. In their model, the introduction of NIRP makes the forward curve flatter than it would be if short rates are expected to be constrained by a zero lower bound. An event study of yield reactions to negative interest rate announcements shows that long rates tend to drop in response to downward revisions in the market's believed location of the lower bound (Grisse et al., 2017). Eisenschmidt and Smets (2017) make a similar point by showing the empirical discontinuity in the shape of the forward curve around the introduction of NIRP in June 2014.

${ }^{19}$ In our data, the difference in yields, before NIRP, between liquid assets and corporate loans is about 10 percentage points.
} 
(APP) announcement in January 2015.

\subsection{Empirical Specifications}

To identify the effect of negative policy rates on bank assets, we compare the credit supply of banks with different levels of exposure to NIRP before and after the ECB's implementation of this policy in June 2014. We examine the effect of NIRP on bank lending using the classic Khwaja and Mian (2008) approach and collapse the monthly credit register data into a single pre- and postNIRP period, considering windows of \pm 3 and \pm 6 months around June $2014 .^{20}$ We compute loan growth at the bank-firm level $\left(\Delta \operatorname{Lan}_{i b}\right)$ as the log difference in total loans granted by bank $b$ to firm $i$ between the post- and the pre-NIRP periods, and estimate the following equation:

$$
\Delta \text { Loan }_{i b}=\alpha \text { Net interbank position }{ }_{b}+\beta \text { Liquidity }_{b}+\gamma^{\prime} \mathbf{X}_{b}+\phi_{i}+\epsilon_{i b}
$$

where the measures of bank exposure to negative interest rates are the net interbank position, measured as interbank loans minus interbank deposits with maturity of up to one week divided by total assets, and liquidity, measured as securities divided by total assets. Since our measures of bank exposure to negative rates are somewhat correlated with other bank characteristics (Table A4), to isolate the effect of NIRP on bank credit supply through the portfolio rebalancing channel, we include the vector $\mathbf{X}_{b}$ of the following bank controls, all measured as of March 2014: bank size (the logarithm of total assets), regulatory capital (Tier 1 capital divided by total assets), and nonperforming loans (impaired loans divided by total assets) — note also that since the model analyzes differences in credit, not levels, we implicitly control for bank fixed effects. ${ }^{21}$

Shifts in credit demand and other unobserved firm-specific shocks are captured by firm fixed effects $\left(\phi_{i}\right)$, so the coefficients of interest $\alpha$ and $\beta$ are identified by comparing the change in credit growth to the same firm in the same period by banks with different NIRP-exposure. Note, however, that there is no systematic relationship between a comprehensive set of firm observables (including size, riskiness measured as distance from default, leverage, and profitability) and the intensity of bank exposure to NIRP, measured either by the net interbank position or liquidity (see

\footnotetext{
${ }^{20}$ Given that the policy was announced in mid-June 2014, we drop all the observations of this month from the sample. We keep the period of analysis relatively short to minimize the impact of other potentially confounding ECB policies. We perform several robustness tests related to the timing of NIRP introduction and the length of windows around it (and we also analyze a very short-term window of \pm 1 month); see Table 3 and related discussion in Section 4.2.

${ }^{21}$ While net interbank position is negatively correlated with size, liquidity is negatively correlated with capital and non-performing loans (Table A4). Moreover, we analyze the same model in other periods to check whether results are driven by NIRP vs. other monetary policies, or by bank unobservables.
} 
Table A5). ${ }^{22}$

Regression estimates are obtained with the Ordinary Least Squares (OLS) estimator and standard errors are double-clustered at the bank and firm level. Double-clustering allows for residual correlation within banks, given that our treatment variable varies at the bank level, as well as within firms, given that credit growth to the same firm may be correlated across banks (for firms with many such relationships and not fully absorbed by firm fixed effects). As the next Section shows, we also perform many different robustness tests. We adopt a similar approach to test for the impact of NIRP on loan rates. We estimate equation 1 taking as dependent variable the change in loan rates applied to loans granted by bank $b$ to firm $i$ between the post- and the pre-NIRP period, focusing on the \pm 6 month window around June 2014 (summary statistics are reported in Table 1).

Then we examine the impact of NIRP on the real economy using a range of firm-level outcomes and a standard methodology used, e.g., in Khwaja and Mian (2008), Iyer et al. (2014), Cingano et al. (2016), Jiménez et al. (2017) and Jiménez et al. (2019). We focus on three firm-level outcomes: total credit growth, investment (fixed assets growth), and wage bill growth in the following specification:

$$
\Delta{\text { Firm } \text { Outcome }_{i}=\alpha \text { Net interbank position }}_{i}+\beta \text { Liquidity }_{i}+\gamma^{\prime} \mathbf{X}_{i}+\psi_{p}+\phi_{s}+\hat{\delta}_{i}+\epsilon_{i}
$$

where the first firm-level outcome we analyze is the change in total credit at the firm level, calculated as the log difference in total bank credit to firm $i$ between the pre- and post-NIRP periods. The key explanatory variables are the firm-level weighted average of the net interbank position and liquidity of all of the firm's lenders, measured before the introduction of NIRP in March 2014. Similarly, the bank control variables $\left(\mathbf{X}_{b}\right)$ are the same as in Equation 1 and are measured before the announcement of NIRP and are calculated as weighted averages of the bank-level variables for each firm's lenders. The firm-specific weights are given by the share of total credit provided by each lender to the firm $i$ in March 2014. In addition to firm's province $\left(\psi_{p}\right)$ and industry $\left(\phi_{s}\right)$ fixed effects, we account for unobserved growth opportunities at the firm level with estimates of firm

\footnotetext{
${ }^{22}$ We test for the balancing of covariates computing the normalized difference between each quartile average and the average in the other three quartiles. Following Imbens and Wooldridge (2009), we analyze the normalized differenceswhich are the differences in averages over the square root of the sum of the variances-as results do not depend on sample size. Imbens and Wooldridge (2009) propose as a rule of thumb a 0.25 threshold in absolute terms, i.e. two variables have "similar" means when the normalized difference does not exceed one quarter. Results confirm that firm observables are well balanced across the distribution of bank exposure to NIRP.
} 
credit demand $\left(\hat{\delta}_{i}\right)$ obtained from the previous within-firm model of credit growth in Equation $1 .^{23}$

In addition to total firm-level credit as dependent variable, we study responses to NIRP of net investment, defined as the growth rate of fixed assets, and the growth rate of the wage bill, two key components of aggregate output. We analyze firm-level real effects in the subsample of manufacturing firms; ${ }^{24}$ however, for completeness, we report the analysis for the full sample of firms. For this test, we focus on the \pm 6 month window, as firm balance sheet data are available on a yearly basis. The dependent variables are thus computed as growth rates between end-2013 and end-2014 values.

\section{Credit Supply}

\subsection{Main Results}

Baseline Results. Table 2 shows the results from our baseline lending regressions for two time windows: \pm 3 and \pm 6 months around June 2014. In each case, we start by including separately the net interbank position and liquidity (respectively, column 1 and 2) and then we include both variables at the same time (column 3).

The coefficient on the net interbank position is positive, statistically significant and stable across model specifications, and indicates that banks with greater net interbank position before NIRP experience higher credit supply after the introduction of negative interest rates than other banks. The estimated effect of the policy is economically significant. One standard deviation increase in net interbank position is associated with an increase of 1.3 percentage points in credit supply after 3 months, relatively to less exposed banks (based on the coefficient of column 3 of Table 2). This effect increases to 1.8 percentage points after 6 months.

The estimated coefficient on bank liquidity is also positive, suggesting that banks with more liquid balance sheets react to NIRP by expanding credit supply relatively more than less liquid banks. The magnitude of the effect of liquidity is similar to that of the net interbank position, as a change in one standard deviation of liquidity is associated with an increase of credit supply by 0.8 percentage points after 3 months and 1.1 percentage points after 6 months.

The comparison between the effects of these two variables and the average growth rate of credit of $-1.9 \%$ shows that these effects are economically sizable. This result reinforces our conjec-

\footnotetext{
${ }^{23}$ See Cingano et al. (2016) or Bofondi et al. (2018) for further details on this approach.

${ }^{24}$ We use the classification Ateco 2002 provided by the National Institute of Statistics (ISTAT), the Italian National Institute of Statistics, which include firms with two-digit industry codes between 15 and 37 in the manufacturing sector.
} 
ture that NIRP affects banks through liquidity management and, interestingly, is the opposite of how the bank lending channel works in normal times, when banks with less liquid balance sheets react more to changes in monetary policy (Kashyap and Stein, 2000).

The results in Table 2 provide evidence for a portfolio rebalancing channel of monetary policy transmission from liquidity to credit supply in an environment of negative interest rates.

The Retail Deposits Channel. As discussed previously, negative policy rates can also affect banks' credit supply through a compression in deposit margins. Given that banks may generally be unwilling to pass negative interest rates to retail depositors, there is a potential cost associated to higher retail deposits when monetary policy rates become negative.

That said, the retail deposit channel may be inactive for the following reasons. First, despite the fact that retail deposit rates are generally considered sticky at zero, it is worth noting that in practice this floor may not be binding, neither at zero nor at another level, because of the cost of holding cash. ${ }^{25}$ Second, our data indicate that banks with a funding structure more skewed toward retail deposits (measured in \% of assets in March 2014) increase fees on banking services after the introduction of NIRP, possibly offsetting the income loss from a compression of intermediation margins. ${ }^{26}$ This correlation is also present in the cross-section of banks, when we control for bank size, capital, liquidity, and non-performing loans (Table A1).

If the portfolio rebalancing channel is the main mechanism through which NIRP impacts bank credit supply, then it should be robust to controlling for retail deposits. In column 4 of Table 2 we control for banks' reliance on retail deposits, as a share of total assets. The results show no evidence of a retail deposits channel regardless of the time windows considered. Moreover, the coefficient estimates on our key NIRP-exposure variables remain unchanged. ${ }^{27}$

Potentially Confounding Policies. As discussed in Section 2, our sample period raises the potential concern that other monetary policies may bias our results insofar as bank responses to these policies are correlated with their March 2014 net interbank and liquidity positions and they affect bank credit. Such worries may extend especially to the TLTRO. The program was announced in

\footnotetext{
${ }^{25}$ It was reported that several German banks charged negative interest rates on large customer deposits in 2016. See Financial Times (August 11, 2016).

${ }^{26}$ Recent reviews of country experiences conclude that bank profitability generally remained resilient, alleviating concerns about a possible contraction in credit (see, e.g. Arteta et al. (2018), Altavilla et al. (2018), IMF (2017), and Lopez et al. (2018)). The experience of Denmark and Sweden, in particular, shows that NIRP did not reduce bank profitability due to banks' adoption of higher fees and commissions for banking services (Turk, 2016; Madaschi and Pablos Nuevos, 2017). More generally, the evidence indicates that the net interest margins and bank profitability are quite stable and do not react to monetary policy (Drechsler et al., 2018).

${ }^{27}$ See Section 4.2 for additional evidence inconsistent with the retail deposits channel.
} 
June 2014 and was first implemented in September 2014 through 8 quarterly auctions. According to the TLTRO's guidelines set by the ECB, the program take-up has a maximum threshold (or "borrowing allowance") equal to $7 \%$ of the total amount of bank loans to non-financial corporations and households (including non-profit institutions serving households) resident in Member States whose currency is the Euro, except loans to households for house purchases, as of April 2014. Based on the supervisory data, we construct a bank-level measure of ex-ante "capacity to borrow under the TLTRO" as the share of the outstanding amount of loans and net lending to euro area non-financial corporations and households, excluding loans to households for house purchase, divided by total assets, as of end-April 2014. In the last column of Table 2, we add this additional variable among the bank controls and we show that differences in borrowing limits under the TLTRO are not associated with changes in loan supply immediately after June 2014. Furthermore, our coefficients of interest (net interbank position and liquidity) remain statistically significant with very similar magnitude to the baseline coefficients. ${ }^{28}$

Another relevant and innovative ECB policy is the first LSAP QE (APP). However, the QE announcement took place on January 22, 2015, that is, more than 3 months after the end of the time window of our baseline results. As a result, QE is unlikely to affect our estimates. In Section 4.3 we focus on QE to test whether it also affected credit supply through a portfolio rebalancing channel.

Nevertheless, to further address any residual concerns that our results may be driven by other ECB policies in the time window of our the baseline regressions-such as the second reduction of deposit rates, the implementation of the TLTRO or the very limited purchases of asset-backed securities and covered bonds announced in September 2014 (all discussed in Section 2)-we report the results of equation 1 in which we compute loan growth as the log difference in total loans granted between July 2014 (the 1-month post-NIRP window) and April 2014 (the 1-month preNIRP window), taking into account that the introduction of NIRP was already expected in May (Wu and Xia, 2017) and therefore dropping May and June 2014 from the sample. As seen in Table A6, evidence for the portfolio rebalancing channel is present even in a narrowly defined time window, which rules out effects from any other ECB policies announced or executed in September 2014.

\footnotetext{
${ }^{28}$ This is consistent with Benetton and Fantino (2018) who show that banks more exposed to the TLTRO start to reduce interest rates to firms only in the second and third quarter of 2015, beyond our sample period.
} 


\subsection{Robustness of the Baseline}

In Table 3 we test the robustness of our benchmark specification for loan volume regressions to a number of different data treatments and subsamples, in an effort to alleviate remaining concerns about identification. In subsequent analysis, we take the specification in column 3 of Table 2, in which we jointly include the net interbank position and liquidity, as our preferred baseline specification and focus on the \pm 3 month period around June 2014 .

We start by saturating our preferred baseline specification with control variables regarding banks' liability structure, namely secured repo funding, foreign funding (deposits from non-residents), bank-issued securities, and interbank deposits (all expressed in \% of total assets). While some of the coefficients on these additional controls are statistically significant, adding these variables leaves our coefficients of interest statistically significant and with almost identical size (column 1). Notice that in this specification the coefficient on retail deposits is positive and statistically significant at the $10 \%$ level, contrary to predictions of the retail deposits channel.

In columns 2 and 3 we further explore the retail deposits channel. First, we remove net interbank position and we leave retail deposits with the standard bank level controls (column 2). Second, we restrict the analysis to relatively large firms (with above-median total assets in March 2014), which makes our results more directly comparable to Heider et al. (2019), whose sample includes large firms that borrow in the syndicated loan market (column 3). In both columns, the coefficient of retail deposits is positive and statistically insignificant which is further evidence against the retail deposits channel.

Second, we consider the possibility that the announcement of NIRP led to an increase in the value of securities on bank balance sheets, confounding our results. To make sure that our result on bank liquidity—defined as securities over assets-is not driven by these revaluation gains, we control for a measure of windfall gains from the repricing of securities. ${ }^{29}$ While this measure is positively correlated with liquidity (the correlation coefficient is 0.56 ), its inclusion in the model does not affect the estimated coefficient on bank liquidity, which remains positive and significant,

\footnotetext{
${ }^{29}$ To compute the windfall gain, we follow the approach of Acharya et al. (2019). For each security in the bank's securities portfolio, we calculate the change in price around the NIRP announcement (the difference between the price at end-June 2014 and that at end-April 2014) and multiply these price changes for the holdings of each security outstanding in the bank portfolio before the announcement (end-April 2014). Finally, we add up the individual gains over all the securities in bank portfolios and express them as \% of total equity. Since we also know in which portfolio each security is held, we restrict our analysis to securities held in the marked-to-market portfolios where unrealized changes in fair value are recognized in the income statement ("held for trading" portfolio) or in the balance sheet in the comprehensive income ("available for sale" portfolio). Further, including the changes in value of the securities in the "held to maturity" portfolios leaves the results unchanged.
} 
and unchanged in size (column 4). As we will show carefully in the next section, this positive effect of liquidity is not present in placebo dates or after previous expansionary monetary policy announcements (despite of windfall gains in previous softer monetary policy actions).

Third, we consider an alternative measure of bank exposure to NIRP. Measuring this exposure at end-March 2014 could miss adjustments that banks may have undertaken ahead of the ECB decision to cut its deposit facility rate to negative levels on June 11, 2014. However, as our data on interbank market participation are available at a quarterly basis, the only other date available to measure the net interbank position and liquidity is end-June 2014. But this is an ex-post measure and may reflect adjustments that took place between June 11 and June 30, 2014. That said, using end-June 2014 exposure to NIRP as our key regressors in the lending regressions leaves our main results unchanged (column 5).

Fourth, we consider an alternative estimator. In column 6 we estimate the baseline specification with Weighted Least Squares (WLS), taking the logarithm of loan size as weight. The estimates show that the point estimate on the net interbank position and liquidity are similar to the coefficient estimates in the unweighted (OLS) regressions.

Lastly, we consider alternative timings of NIRP. We start by extending the time window to \pm 12 months around June 2014. Even when we significantly expand the period of analysis, we still find a positive and significant effect of the exposure variables on credit supply (column 7). Then, we take into account the fact that the pass-through from negative policy rates to overnight interbank rates was not simultaneous: EONIA turned negative in August. Given that these rates remained positive through most of the period between June and August 2014, we remove observations for these months and redefine the \pm 3 window around the period June-August 2014. Column 8 shows that the baseline effects remain statistically significant and close in magnitude to that of Table 2, column 1. Moreover, given evidence that the introduction of NIRP in June 2014 was expected the month before (Wu and Xia, 2017), we also re-center the baseline analysis on the \pm 3 months around May and June 2014-excluding the observations of these months from the sample. We find that our results are unaffected by the shift of our time window by one month (column 9).

\subsection{Falsification Tests}

An important identifying assumption in our empirical framework is "parallel trends," which would be violated if our NIRP bank exposure variables were correlated with pre-NIRP loan growth. To rule out pre-existing trends in loan growth for banks with different net interbank and liquidity 
positions, we run a set of regressions that are similar to our baseline specification (Table 2, column 3 ), centering the \pm 3 and \pm 6 month windows on different months before the NIRP announcement. The results are reported in Table 4, which shows the estimated coefficients of the net interbank position and liquidity (both measured as of March 2014). The top panel considers the \pm 3 months window and reports results centered around December 2013, January 2014, and February 2014, which is the last month for which the post-NIRP 3-month window does not include June 2014 (November 2013-May 2014). For the same reason, the bottom panel reports results for the \pm 6 months window around September, October, and November 2013. The results indicate that the parallel trends assumption is valid given that the coefficients estimated in the months before NIRP are always close to zero and statistically insignificant. ${ }^{30}$

Next we assess to what extent NIRP differs from conventional and unconventional monetary policies. For this purpose we conduct three additional tests. These tests center the period of analysis around three different monetary policy events. First, we consider the last time the ECB reduced the policy rates before NIRP - that is, when the ECB decreased the interest rate on the deposit facility by 25 basis points to $0 \%$ on July 11,2012 . On that occasion, the policy rate cut translated into a decrease in short-term yields, while the long end of the yield curve remained largely unchanged (Figure 3, panel a). The second test is for the first announcement of forward guidance-in July 2013-aimed at influencing market expectations of future level of interest rates. ${ }^{31}$ On that occasion, the deposit facility rate stayed unchanged at $0 \%$ and the announcement did not lead to a downward shift and simultaneous flattening of the yield curve, as it happened in June 2014 with NIRP (Figure 3, panel b). ${ }^{32}$ Third, we consider the announcement of the first LSAP QE in January 2015. In that event, the yield curve flattened (Figure 3, panel d), as it did after the introduction of negative rates, even though the deposit facility rate remained unchanged at $-0.20 \%{ }^{33}$

The results of tests are reported in Table 5. Similar to the baseline regressions, we analyze the impact of other monetary policy announcements on bank credit supply in the \pm 3 (panel A) and

\footnotetext{
${ }^{30}$ The coefficient of liquidity in column 1 of the top panel is significant, but negative.

${ }^{31}$ At the introductory statement to the press conference, on July 4, 2013, Mario Draghi stated that "[t]he Governing Council expects the key ECB interest rates to remain at present or lower levels for an extended period of time."

${ }^{32}$ We find the same effects after the second announcement of forward guidance, in January 2014. Above we focus on the first announcement as we are interested in the introduction of unconventional monetary policy and also because there is evidence that the first announcement generated most of the effects induced by forward guidance on the overnight indexed swaps rates. By contrast, the second announcement had a negative but smaller effect, especially at longer horizons (Hubert and Labondance, 2018).

${ }^{33}$ Gambetti and Musso (2017) also find that the QE announcement in January 2015 was accompanied to a flattening of the yield curve. The authors explain that the announcement was to some extent expected. However, they report market polls and anecdotal evidence from newspapers, according to which, the large scope of asset purchases was not fully expected and hence did surprise the markets.
} 
\pm 6 (panel B) month windows around these dates. We measure banks' net interbank position and liquidity before the policy announcements, that is, in June 2012, June 2013, and December 2014, respectively. We find that during the previous rate cut and the forward guidance announcements, the impact of monetary policy is very different. In case of the July 2012 rate cut, the coefficients of net interbank position and liquidity are both negative and statistically significant. For the liquidity variable, this results is consistent with the standard bank lending channel of transmission of monetary policy (Kashyap and Stein, 2000), according to which a monetary easing benefits especially banks with less liquidity.

In the 3 months around the forward guidance announcement in July 2013, we find that the coefficient on the net interbank position is again negative while the coefficient on liquidity is positive (though significantly smaller than during NIRP). However, when we broaden the window, these results are no longer statistically significant.

Finally, for the QE (LSAP introduction's) announcement, we find that more liquid banks expand credit supply, consistent with the evidence of portfolio rebalancing effects of QE programs in the U.S. (Krishnamurthy and Vissing-Jorgensen, 2013) and the euro area (Albertazzi et al., 2018). But the coefficient of net interbank position is smaller and not statistically significant. This result is not surprising given that QE is not associated with a drop in the short-term (monetary) rates.

Taken together, our robustness and falsification tests suggest that the NIRP announcement activates a portfolio rebalancing mechanism. Banks rebalance their portfolios from liquid assets towards credit supply. This rebalancing is not at play in previous months or after interest rate cuts in positive territory and close to the ZLB or after forward guidance announcements. But QE announcements generates effects that are similar to NIRP (in the sense of portfolio rebalancing, but with differences between short-term interbank positions and the broader liquid balance sheets).

\subsection{Heterogeneity: Firm Risk and Size}

Thus far, our findings show that NIRP-affected banks expand credit supply and, in general, they rebalance portfolios away from liquid assets to credit supply. It is important to understand whether there is also a portfolio rebalancing within the loan portfolio, in other words whether credit increases homogeneously across firms, or whether it does so more towards certain types of firms.

We focus on two key firm dimensions - riskiness and size - which are relevant for the following reasons. First, riskier and smaller firms are typically more credit constrained and monetary easing should lead banks to expand credit towards marginal, financially-constrained borrowers 
too. Second, we would like to pin down more precisely the channel driving our results. If banks rebalance their portfolios towards higher yielding assets, they should expand credit especially towards higher yielding loans. Riskiness and size are good proxies for the yield banks can extract from borrowers because risky and small borrowers are typically charged higher loan spreads and have fewer opportunities to substitute across lenders. We split the sample between (ex-ante) small and large firms, and firms with (ex-ante) weak and strong credit ratings, around the median of the distribution of total assets and that of the Altman z-score respectively (at end-March 2014).

The results are shown in Table 6 , where the first three columns refer to the \pm 3 month window and the last three columns to the \pm 6 month window. We are interested in testing whether the expansion of credit is stronger for certain type of firms, therefore we include bank fixed effects in all the specifications to absorb unobserved bank heterogeneity and focus on the interaction terms between firm characteristics and the banks' net interbank position and liquidity, respectively. The results consistently show that the relative expansion of credit supply by relatively more NIRPexposed banks, measured either by the net interbank position (panel A) or by the liquidity ratio (panel B), is significantly higher for ex-ante riskier firms (with high z-score, low credit rating) and smaller firms.

Note that the increase in ex-ante risk-taking by more NIRP-affected banks does not translate into higher levels of ex-post NPLs. In Table A7 we report bank-level regressions where the dependent variable is the change in the NPL ratio the one year after the introduction of NIRP and the regressors are bank characteristics as of March 2014. The results show that more NIRP-exposed banks do not experience a deterioration in loan quality, which suggests that banks do not engage in "excessive" risk-taking. ${ }^{34}$

\subsection{Transmission to Lending Rates}

Our analysis so far has focused on banks' adjustment to NIRP regarding loan volumes. A thorough understanding of how negative policy rates impact the economy also requires documenting the pass-through from policy rates to lending rates. Moreover, documenting a pass-through of negative policy rates to bank loan rates would strengthen a supply-side interpretation of the impact of NIRP on bank credit.

\footnotetext{
${ }^{34}$ Another potential source of heterogeneity is bank capital, as banks with lower capital ratios may be constrained in rebalancing their portfolio toward more credit and less liquid assets. In unreported regressions, we test whether banks' responses to the introduction of NIRP varies with the level of ex-ante bank capital. We find some weak evidence that the effect of NIRP on the credit supply is larger for high-capital banks, but results are not robust.
} 
Table 7 reports the estimates for gross loan rates. As in the loan volume regressions, empirical identification relies on comparing the rates of loans granted to the same firm by at least two banks with different exposure to the policy, before and after NIRP introduction. Across columns, our results indicate that negative policy rates pass-through to lending rates through banks' net interbank position and the broader measure of liquidity. Using the estimates in column 3 of Table 7, which refer to the total cost of borrowing, a change in one standard deviation in the banks' net interbank position (liquidity) leads to $6.9 \%$ (4.4\%) reduction of loan rates after 6 months; this effect is economically meaningful.

Finally, our results are robust to controlling for banks' reliance on retail deposits and their "capacity to borrow under the TLTRO" (see Section 4.1 for how we measure capacity to borrow) and show no evidence that NIRP affects loans rates through the retail deposit channel in the case of Italy (columns 4 and 5). Hence, the retail deposit channel is inactive in the supply of credit volume and also in change of loan rates.

\section{Real Effects}

Our lending analysis shows that NIRP-exposed banks increase credit supply in response to NIRP. Does this positive effect on credit translate into better outcomes in the real sector? To test for real effects of NIRP, we start by running firm-level regressions where the dependent variable is the growth rate of total firm-level credit in the \pm 6 month window around June 2014. The net interbank position and liquidity are defined as the firm-level average of the net position in the interbank market and of liquid assets of the firms' lenders in March 2014, weighted by the share of total credit granted to the firm by each lender. We control for firm-level demand with the estimated firm fixed effects from the firm-bank loan-growth regressions, and location and industry fixed effects.

The results-reported in the first column of Table 8-show that the coefficients on the net interbank position and liquidity are positive and statistically significant, both in the sample of manufacturing firms (panel A) and in the full sample of manufacturing and services firms (panel B). Using the estimates for the full sample, we find that a one standard deviation change in a firm's lenders' net interbank position (liquidity) is associated with a 2.8 (1.4) percentage point increase in total credit for that firm. These effects are economically large considering that the average change in total firm-level credit in the \pm 6 month window is 1.7 percent. This result further emphasizes 
the unique features of the bank lending channel of NIRP transmission to the real economy.

Next, we analyze whether more credit translates into stronger firm performance. In the remaining columns of Table 8 we use the same specification but consider the following firm outcomes: the growth rate of fixed assets (investment expenditure, column 2) and the growth of total payroll (wage bill, column 3), which are key components of aggregate output. In the sample of manufacturing firms (panel A) we find that firms borrowing (prior to the NIRP introduction) from lenders with greater exposure to NIRP expand economic activity relatively more. Considering estimate for the net interbank position, firm investment increases by 5.6 percentage points and the wage bill by 3.5 percentage points more for firms borrowing from banks with (one standard deviation) larger ex-ante net interbank position. ${ }^{35}$ Firms that borrow from banks with higher liquidity ratios only experience higher investment: a one standard deviation increase in banks' liquidity is associated with a 5.2 percentage point increase in firm investment.

\section{Conclusions}

Despite the importance of negative monetary policy rates for our broader understanding of finance and macroeconomics, systematic evidence on their transmission to the economy through the banking system remains scarce. Not only do several major economies (such as the euro area and Japan) currently have negative rates, but, in the current low-interest rate environment, NIRP may become even more important in the future.

We study the impact of NIRP exploiting ECB's introduction of negative nominal policy rates in mid-2014 and comprehensive micro data from Italy. First, we document an increase in the growth rate of total bank credit after the introduction of NIRP with aggregate data in the time series. Second, we use loan-level data to show that NIRP works through a portfolio rebalancing channel, inducing banks to rebalance their portfolios from liquid assets to credit supply. The announcement of NIRP shifted the entire yield curve downwards, in a way that the yields of the safer assets were relatively more affected by the downwards shift of the yield curve (thereby widening the wedge between the yields of safer, liquid assets vs. riskier assets). Previous rate cuts just above the ZLB or forward guidance announcements did not induce these shifts and consequently did not cause a similar portfolio rebalancing.

Exploiting cross-sectional variation in ex-ante short-term net interbank position and ex-ante

\footnotetext{
${ }^{35}$ Results for wage bill growth are similar in the full sample of firms (panel B). This is not the case for investment, as, arguably, manufacturing firms are more dependent on credit to finance fixed assets.
} 
liquid balance sheet position of banks, we also show that more NIRP-affected banks expand credit supply, especially to riskier and smaller firms, and cut loan rates, thereby inducing sizable firmlevel real effects, including on firm-level investment.

\section{Acknowledgements}

We thank David Arseneau, Gabriel Chodorow-Reich, Giovanni Dell'Ariccia, Davide Fantino, Dimas Mateus Fazio, Xavier Freixas, Luca Fornaro, Michael Gofman, Lucyna Gornicka, Luca Guerrieri, Kebin Ma, David Martinez Miera, Marco Pagano, Rafael Repullo, Ken Rogoff, Kasper Roszbach and seminar participants at the IMF, the Bank of Italy, USC Dornsife INET, the University of Milano Bicocca, the 6th Workshop in Macro Banking and Finance (Alghero 2018), the III MadBar Workshop (Madrid 2018), the 10th Baffi Carefin International Banking Conference (Milan 2018), the ECB workshop on Money Markets and Central Bank Balance Sheets (Frankfurt 2018), the Workshop in Empirical Monetary Economics (Paris 2018), the XIII Annual Conference on Financial Stability and Banking (Sao Paulo 2018), the TAU Finance Conference (Tel Aviv 2018), the Federal Reserve Day-Ahead Conference (Atlanta 2019), and the ASSA Meetings (Atlanta 2019) for useful comments. Camelia Minoiu is grateful to the Wharton Financial Institutions Center and the Management Department at the University of Pennsylvania for their hosting during the development of this research project. José-Luis Peydró acknowledges financial support from ECO2015-68182-P (MINECO/FEDER, UE) and from the European Research Council Grant (project 648398). The views expressed herein are those of the authors and should not be attributed to the Bank of Italy, the Federal Reserve Board, the IMF, their management, or policies. 


\section{References}

Acharya, V., Eisert, T., Eufinger, C., and Hirsch, C. (2019). Whatever it Takes: The Real Effects of Unconventional Monetary Policy. Review of Financial Studies, Forthcoming.

Acharya, V. V. and Merrouche, O. (2012). Precautionary Hoarding of Liquidity and Interbank Markets: Evidence from the Subprime Crisis. Review of Finance, 17(1):107-160.

Acharya, V. V., Pierret, D., and Steffen, S. (2016). Lender of Last Resort versus Buyer of Last Resort:

Evidence from the European Sovereign Debt Crisis. mimeo. New York University.

Adrian, T. and Shin, H. S. (2011). Financial Intermediaries and Monetary Economics. In Friedman,

B. M. and Woodford, M., editors, Handbook of Monetary Economics, volume 3a, pages 601-650. Elsevier.

Albertazzi, U., Becker, B., and Boucinha, M. (2018). Portfolio rebalancing and the transmission of large-scale asset programmes: evidence from the euro area. ECB Working Paper 2125, European Central Bank, Frankfurt.

Allen, F. and Rogoff, K. S. (2011). Asset Prices, Financial Stability and Monetary Policy. In Jansson, P. and Persson, M., editors, The Riksbank's Inquiry into the Risks in the Swedish Housing Market, pages 189-218. Sveriges Riksbank, Stockholm.

Altavilla, C., Boucinha, M., and Peydró, J.-L. (2018). Monetary policy and bank profitability in a low interest rate environment. Economic Policy, 33(96):531-586.

Altavilla, C., Carboni, G., and Motto, R. (2015). Asset purchase programmes and financial markets: lessons from the euro area. Technical report, ECB Working Paper.

Altman, E. I. (1968). Financial ratios, discriminant analysis and the prediction of corporate bankruptcy. The Journal of Finance, 23(4):589-609.

Angelini, P., Nobili, A., and Picillo, C. (2011). The Interbank Market after August 2007: What Has Changed, and Why? Journal of Money, Credit and Banking, 43(5):923-958.

Arce, O., Garcia-Posada, M., Mayordomo, S., and Ongena, S. (2018). Adapting lending policies when negative interest rates hit banks' profits. Electronic copy available at: https:/ / ssrn.com/abstract=3161924.

Arseneau, D. M. (2017). How Would US Banks Fare in a Negative Interest Rate Environment? Finance and Economics Discussion Series 2017-030, Board of Governors of the Federal Reserve System, Washington DC.

Arteta, C., Kose, A., Stocker, M., and Taskin, T. (2018). Implications of negative interest rate poli- 
cies: An early assessment. Pacific Economic Review, 23(1):8-26.

Baldo, L., Hallinger, B., Helmus, C., Herrala, N., Martins, D., Mohing, F., Petroulakis, F., Resinek, M., Vergote, O., Usciati, B., et al. (2017). The distribution of excess liquidity in the euro area. Occasional Paper 200, European Central Bank, Frankfurt.

Basten, C. and Mariathasan, M. (2018). How Banks Respond to Negative Interest Rates: Evidence from the Swiss Exemption Threshold. CESifo Working Paper 6901, CESifo, Munich.

Benetton, M. and Fantino, D. (2018). Competition and The Pass-Through of Unconventional Monetary Policy: Evidence from TLTROs. unpublished working paper.

Bernanke, B. S. (2016). Modifying the Fed's policy framework: Does a higher inflation target beat negative interest rates? Brookings.

Bernanke, B. S. (2017). Monetary Policy in a New Era. Prepared for conference on Rethinking Macroeconomic Policy, Peterson Institute.

Bhattarai, S. and Neely, C. (2016). A Survey of the Empirical Literature on U.S. Unconventional Monetary Policy. Working Paper 2016-021, Federal Reserve Bank of St. Louis.

Bofondi, M., Carpinelli, L., and Sette, E. (2018). Credit Supply During a Sovereign Debt Crisis. Journal of the European Economic Association, 16(3):696-729.

Borio, C. and Zhu, H. (2012). Capital regulation, risk-taking and monetary policy: A missing link in the transmission mechanism? Journal of Financial Stability, 8(4):236-251.

Brunnermeier, M. K. and Koby, Y. (2018). The reversal interest rate: An effective lower bound on monetary policy. Mimeo. Princeton University.

Chakraborty, I., Goldstein, I., and MacKinlay, A. (2016). Monetary stimulus and bank lending. mimeo. University of Pennsylvania.

Cingano, F., Manaresi, F., and Sette, E. (2016). Does Credit Crunch Investments Down? New Evidence on the Real Effects of the Bank-Lending Channel. Review of Financial Studies, 29(10):27372773.

Cœuré, B. (2017). Dissecting the yield curve: a central bank perspective. Welcome remarks at the annual meeting of the ECB's Bond Market Contact Group. Frankfurt am Main.

Curdia, V. and Woodford, M. (2011). The Central-Bank Balance Sheet as an Instrument of Monetary Policy. Journal of Monetary Economics, 58(1):54-79.

D’Amico, S. and King, T. B. (2013). Flow and stock effects of large-scale treasury purchases: Evidence on the importance of local supply. Journal of Financial Economics, 108(2):425-448.

Dell'Ariccia, G., Laeven, L., and Suarez, G. A. (2017). Bank Leverage and Monetary Policy's Risk- 
Taking Channel: Evidence from the United States. Journal of Finance, 72(2):613-654.

Dell'Ariccia, G., Rabanal, P., and Sandri, D. (2018). Unconventional Monetary Policies in the Euro Area, Japan, and the United Kingdom. Journal of Economic Perspectives, 32(4):147-172.

Demiralp, S., Eisenschmidt, J., and Vlassopoulos, T. (2017). Negative interest rates, excess liquidity and bank business models: Banks' reaction to unconventional monetary policy in the euro area. Working Paper 1708, Koc University-TUSIAD Economic Research Forum.

Draghi, M. (2016). Press conference introductory statement. Introductory statement at ECB Press Conference, Frankfurt am Main, March 10, 2016.

Draghi, M. (2017). Press conference introductory statement. Introductory statement at ECB Press Conference, Frankfurt am Main, April 27, 2017.

Drechsler, I., Savov, A., and Schnabl, P. (2018). Banking on Deposits: Maturity Transformation without Interest Rate Risk. NBER Working Paper 24582, National Bureau of Economic Research.

Eggertsson, G. B., Juelsrud, R. E., Summers, L. H., and Wold, E. G. (2019). Negative Nominal Interest Rates and the Bank Lending Channel. NBER Working Paper 25416, National Bureau of Economic Research, Boston.

Eisenschmidt, J. and Smets, F. (2017). Negative interest rates: Lessons from the euro area. unpublished working paper.

Gambetti, L. and Musso, A. (2017). The macroeconomic impact of the ECB's expanded asset purchase programme (APP). Working Paper 2075, European Central Bank, Frankfurt.

Gertler, M. and Karadi, P. (2011). A Model of Unconventional Monetary Policy. Journal of Monetary Economics, 58(1):17-34.

Grisse, C., Krogstrup, S., and Schumachera, S. (2017). Lower-Bound Beliefs and Long-Term Interest Rates. International Journal of Central Banking, 13(3):165-202.

Hartmann, P. and Smets, F. (2018). The First 20 Years of the European Central Bank: Monetary Policy. BPEA Conference Draft, Brookings.

Heider, F., Saidi, F., and Schepens, G. (2019). Life Below Zero: Bank Lending Under Negative Policy Rates. Review of Financial Studies, Forthcoming.

Hubert, P. and Labondance, F. (2018). The Effect of ECB Forward Guidance on the Term Structure of Interest Rates. International Journal of Central Banking, 14(5):193-222.

Hutchinson, J. and Smets, F. (2017). Monetary Policy in Uncertain Times: ECB Monetary Policy Since June 2014. The Manchester School, 85(52):c1-c15.

Imbens, G. W. and Wooldridge, J. M. (2009). Recent developments in the econometrics of program 
evaluation. Journal of Economic Literature, 47(1):5-86.

IMF (2016). Euro Area Policies-Selected Issues. Technical report, International Monetary Fund, Washington DC. IMF Country Report No. 16/220.

IMF (2017). Negative Interest Rate Policies-Initial Experiences and Assessments. Technical report, International Monetary Fund, Washington DC. IMF Policy Paper.

Iyer, R., Lopes, S., Peydro, J., and Schoar, A. (2014). Interbank liquidity crunch and the firm credit crunch: Evidence from the 2007-2009 crisis. Review of Financial Studies, 27(1):347-372.

Jiménez, G., Mian, A. R., Peydró, J.-L., and Saurina, J. (2019). The Real Effects Of The Bank Lending Channel. Journal of Monetary Economics, Forthcoming.

Jiménez, G., Ongena, S., Peydró, J., and Saurina, J. (2012). Credit supply and monetary policy: Identifying the bank-balance sheet channel with loan applications. American Economic Review, 102(5):2121-2165.

Jiménez, G., Ongena, S., Peydró, J., and Saurina, J. (2014). Hazardous times for monetary policy: What do twenty-three million bank loans say about the effects of monetary policy on credit risk? Econometrica, 2(82):463-505.

Jiménez, G., Ongena, S., Peydró, J.-L., and Saurina, J. (2017). Macroprudential Policy, Countercyclical Bank Capital Buffers, and Credit Supply: Evidence from the Spanish Dynamic Provisioning Experiments. Journal of Political Economy, 125(6):2126-2177.

Kashyap, A. K. and Stein, J. C. (1995). The impact of monetary policy on bank balance sheets. In Carnegie-Rochester Conference Series on Public Policy, volume 42, pages 151-195. Elsevier.

Kashyap, A. K. and Stein, J. C. (2000). What do a million observations on banks say about the transmission of monetary policy? American Economic Review, pages 407-428.

Khwaja, A. I. and Mian, A. (2008). Tracing the impact of bank liquidity shocks: Evidence from an emerging market. American Economic Review, 98(4):1413-42.

Krishnamurthy, A. and Vissing-Jorgensen, A. (2011). The Effects of Quantitative Easing on Interest Rates: Channels and Implications for Policy. Brookings Papers on Economic Activity, Fall(2):215265.

Krishnamurthy, A. and Vissing-Jorgensen, A. (2013). The ins and outs of LSAPs. Proceedings Economic Policy Symposium - Jackson Hole.

Lemke, W. and Vladu, A. (2017). Below the zero lower bound: A shadow-rate term structure model for the euro area. ECB Working Paper 1991, European Central Bank.

Lopez, J. A., Rose, A. K., and Spiegel, M. M. (2018). Why Have Negative Nominal Interest Rates 
Had Such a Small Effect on Bank Performance? Cross Country Evidence. Working Paper 201807, Federal Reserve Bank of San Francisco.

Madaschi, C. and Pablos Nuevos, I. (2017). The profitability of banks in a context of negative monetary policy rates: The cases of Sweden and Denmark. Occasional Paper 195, European Central Bank, Frankfurt.

Martinez-Miera, D. and Repullo, R. (2017). Search for yield. Econometrica, 85(2):351-378.

McKay, A., Nakamura, E., and Steinsson, J. (2016). The power of forward guidance revisited. The American Economic Review, 106(10):3133-3158.

Nakamura, E. and Steinsson, J. (2018). Identification in macroeconomics. Journal of Economic Perspectives, 32(3):59-86.

Peydró, J.-L., Polo, A., and Sette, E. (2017). Monetary policy at work: Security and credit application registers evidence. mimeo. Universitat Pompeu Fabra.

Rajan, R. G. (2005). Has Financial Development Made the World Riskier? In Proceedings - Economic Policy Symposium - Jackson Hole, Federal Reserve Bank of Kansas City, pages 313-369.

Rodnyansky, A. and Darmouni, O. M. (2017). The Effects of Quantitative Easing on Interest Rates: Channels and Implications for Policy. The Review of Financial Studies, 30(11):3858-3887.

Rogoff, K. (2017). Dealing with Monetary Paralysis at the Zero Bound. Journal of Economic Perspectives, 31(3):47-66.

Rogoff, K. S. (2016). The Curse of Cash. University Press, Princeton.

Rostagno, M., Bindseil, U., Kamps, A., Lemke, W., Sugo, A., and Vlassopoulos, T. (2016). Breaking through the zero line: The ECB's negative interest rate policy. Presentation at Brookings Institution.

Ruge-Murcia, F. J. (2006). The expectations hypothesis of the term structure when interest rates are close to zero. Journal of Monetary Economics, 53(7):1409-1424.

Sette, E. and Gobbi, G. (2015). Relationshio Lending During a Financial Crisis. Journal of the European Economic Association, 13(3):453-481.

Stein, J. C. (2013). Overheating in Credit Markets: Origins, Measurement, and Policy Responses. Speech at the "Restoring Household Financial Stability after the Great Recession: Why Household Balance Sheets Matter" research symposium sponsored by the Federal Reserve Bank of St. Louis.

Taylor, J. B. (2009). Economic Policy and the Financial Crisis: An Empirical Analysis of What Went Wrong. Critical Review, 21(2-3):341-364. 
Turk, R. A. (2016). Negative Interest Rates: How Big a Challenge for Large Danish and Swedish Banks? IMF Working Paper 16/198, International Monetary Fund, Washington DC.

Upper, C. (2006). Contagion Due to Interbank Credit Exposures: What Do We Know, Why Do We Know It, and What Should We Know? Working Paper, Bank for International Settlements, Basel.

Wu, J. C. and Xia, F. D. (2017). Negative Interest Rate Policy and Yield Curve. Research Paper 17-34, Chicago Booth. 


\section{Figures and Tables}

Figure 1: Short-term Interbank Rates, January 2014-December 2014

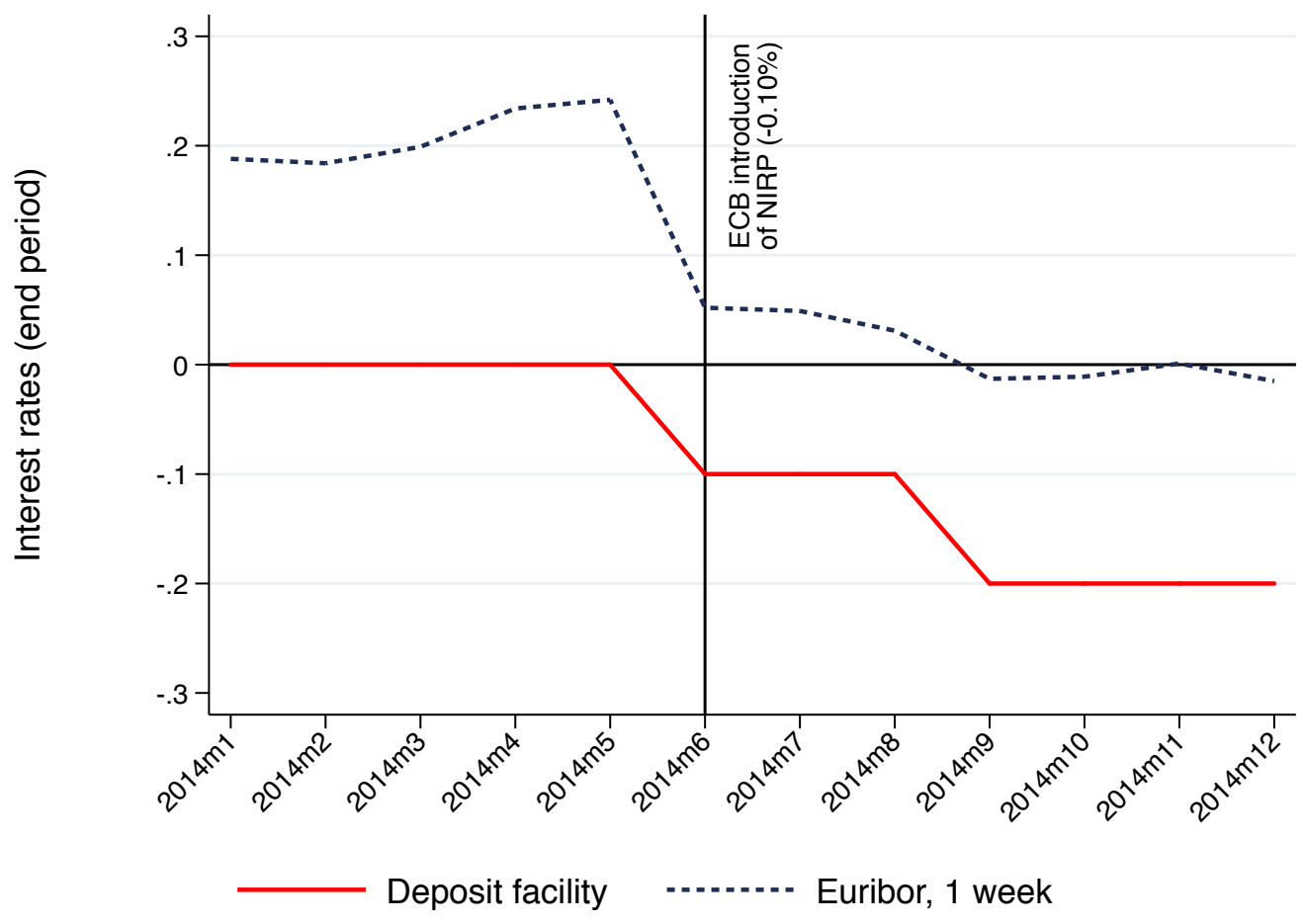

Notes: The chart plots the ECB Deposit Facility rate and the Euribor 1 week interest rate, at a monthly frequency, taking the end-month values. The solid vertical line corresponds to end June 2014, and separates the pre-NIRP (January 2014-June 2014) from the post-NIRP (July 2014-December 2014) windows. Source: Thomson Reuters Eikon. 
Figure 2: Aggregate Credit Growth (year-on-year) to Non-Financial Corporation in Italy, 2014

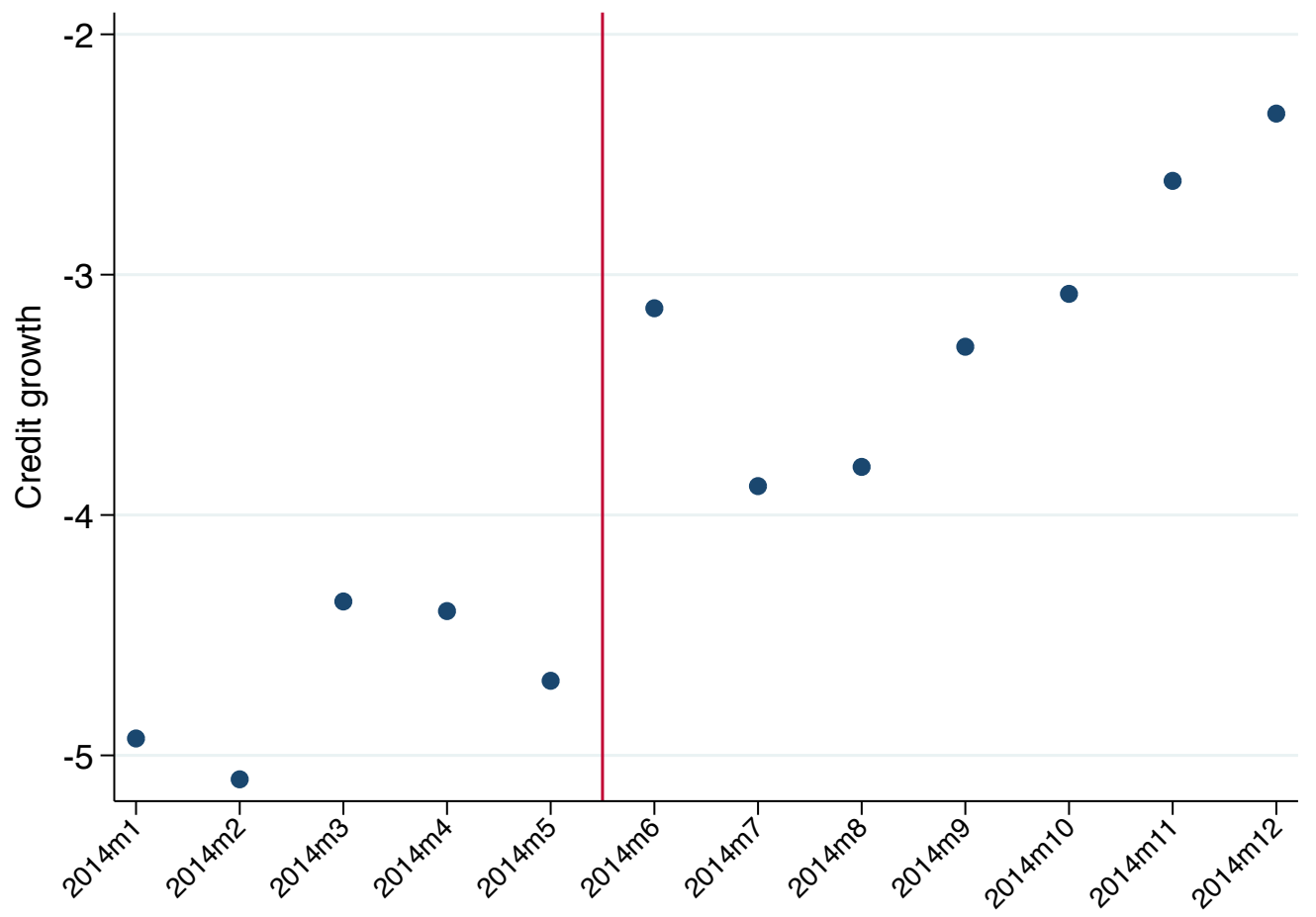

Notes: The chart plots the year-on-year growth rate of total bank credit to non-financial corporations. Source: Bank of Italy. 
Figure 3: Forward Curves with Conventional and Unconventional Monetary Policy

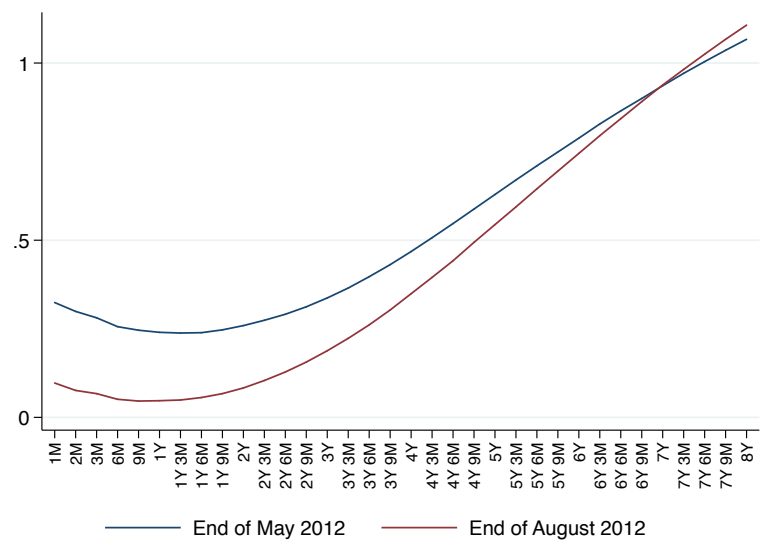

(a) July 2012 (rate cut)

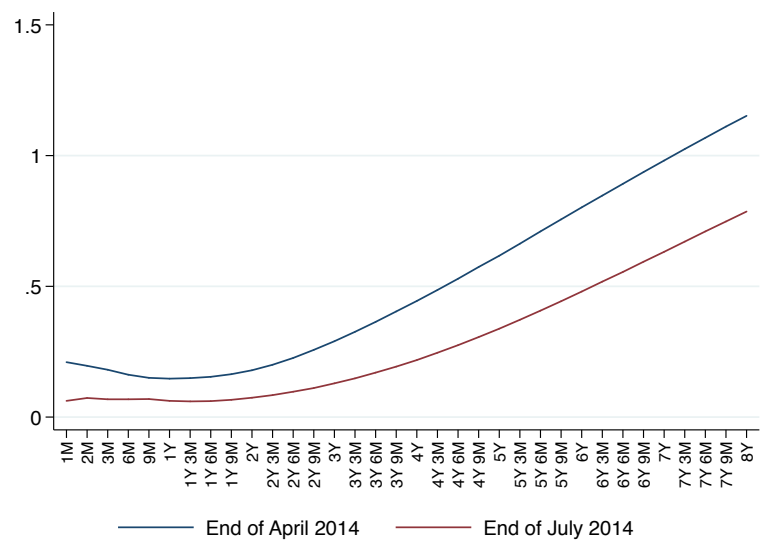

(c) June 2014 (NIRP)

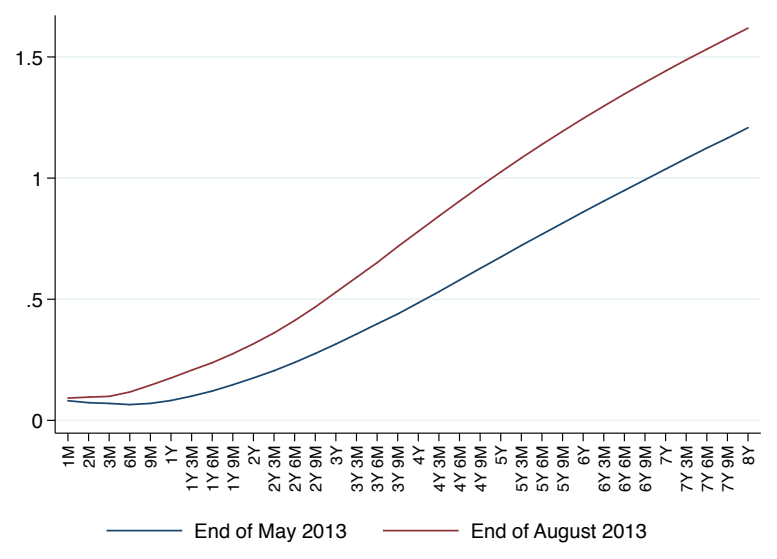

(b) July 2013 (forward guidance)

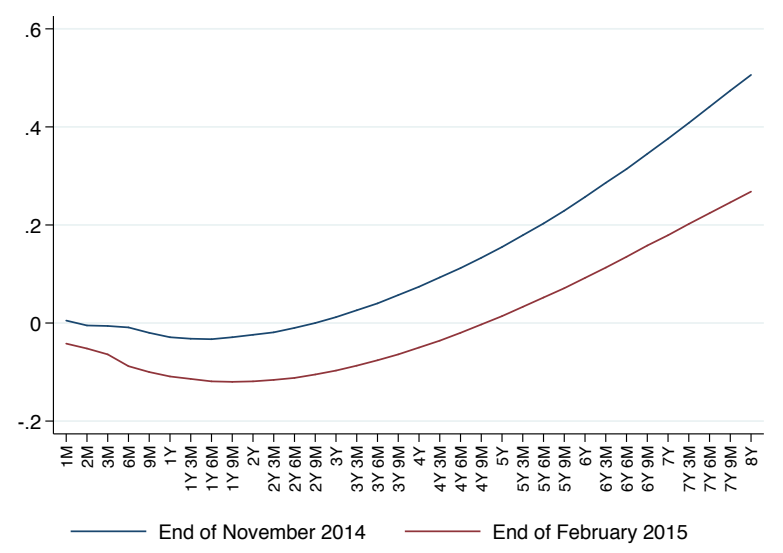

(d) Jan. 2015 (QE (APP))

Notes: The charts plot the yield curves before and after: the ECB interest rate cut of July 2012 (panel a), the first ECB forward guidance announcement in July 2013 (panel b), the ECB introduction of negative policy rates in June 2014 (panel c), and the ECB announcement of QE (expanded asset purchase programme) in January 2015 (panel d). Source: Thomson Reuters Eikon. 
Figure 4: Negative Policy Rates and the Wedge Between Safer and Riskier Assets

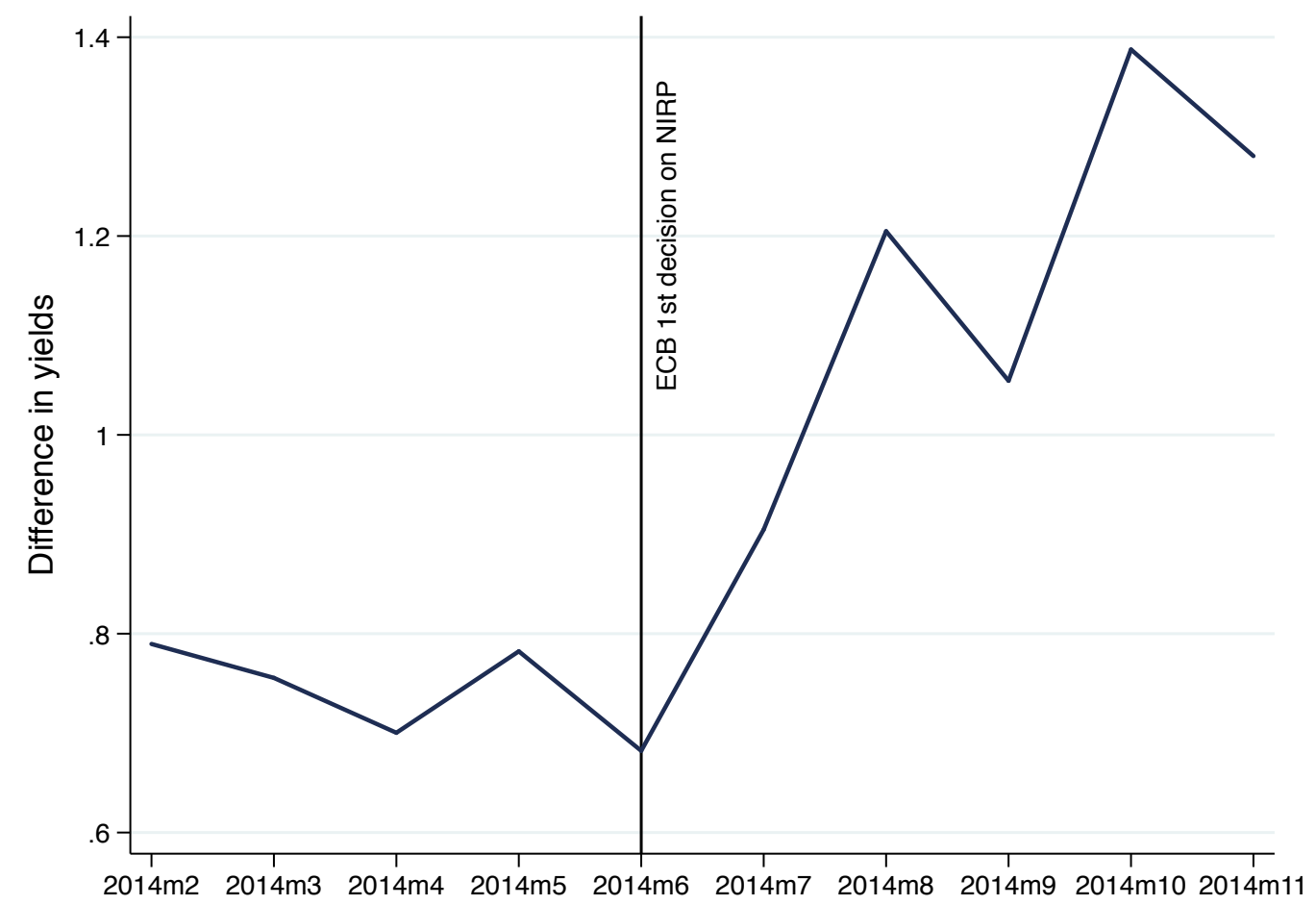

Notes: The chart plots the difference in the yields between the BB European non-financial corporate 5-year bonds index and the European governments 20-year bonds benchmark. For both series monthly data are period averages of daily returns. Source: Thomson Reuters Eikon. 


\section{Table 1: Descriptive Statistics}

Notes: Panel A refers to bank-level variables. Net interbank position is measured as the ratio of interbank loans minus interbank deposits with maturity up to one week, over total assets. Liquidity is the ratio of securities over total assets. Size is defined as the logarithm of total assets. Capital is the ratio of TIER 1 capital over total assets. NPL is non-performing loans scaled by total assets. Retail deposits are measured as a share of total assets. TLTRO is the ratio of total loans to euro area non-financial corporations and households-excluding loans to households for house purchase-over total assets, as of April 2014. Secured Repo is the ratio of secured repo funding over total assets. Liabilities vis-a-vis non resident is the ratio of foreign funding (deposits from non-residents) over total assets. Securities issues is the ratio of bank-issued securities over total assets. Interbank deposits is the ratio of interbank deposits over total assets. Windfall gain is the sum of individual revaluation gains over all the securities in the marked-to-market portfolios around NIRP as a fraction of a bank's total equity. All these variables are measured as of March 2014. Income fees over assets is measured as of June 2014. Panel B refers to loan-level variables. $\Delta$ Loan is measured as log difference between the average total exposure of a given firm with a given bank in the post-NIRP period (July-September 2014) and the correspondent average total exposure in the pre-NIRP period (March-May 2014). Rate is the average rate charged by a given bank to a given firm. Gross rates include commissions and fees. Panel C refers to firm-level variables. $\triangle$ Loan is the loan growth at the firm-month level, calculated as $\log$ difference between the post- and the pre-NIRP period. Net investment is the growth rate of fixed assets between 2014 and 2013. Wage bill growth is the growth rate of the wage bill between 2014 and 2013.

\begin{tabular}{|c|c|c|c|c|}
\hline & Mean & St.Dev. & Median & Obs. \\
\hline \multicolumn{5}{|l|}{ Panel A: Bank-level variables } \\
\hline Net interbank position, March 2014 & 4.200 & 10.810 & 1.862 & 95 \\
\hline Liquidity, March 2014 & 28.670 & 13.950 & 25.940 & 95 \\
\hline Size & 7.667 & 2.310 & 7.598 & 95 \\
\hline Capital & 8.533 & 5.768 & 7.079 & 95 \\
\hline NPL & 4.348 & 3.555 & 3.868 & 95 \\
\hline Retail deposits, March 2014 & 45.260 & 16.120 & 44.650 & 95 \\
\hline TLTRO & 35.670 & 12.560 & 36.370 & 95 \\
\hline Secured Repo & 2.918 & 8.172 & 0.000 & 95 \\
\hline Liabilities vis-a-vis non-resident & 1.390 & 2.240 & 0.245 & 95 \\
\hline Securities issued & 14.520 & 10.200 & 14.560 & 95 \\
\hline Interbank deposits & 13.780 & 9.785 & 12.760 & 95 \\
\hline Windfall gain & 1.378 & 1.525 & 0.919 & 95 \\
\hline Income fees over assets (\%) & 0.124 & 0.107 & 0.099 & 83 \\
\hline \multicolumn{5}{|l|}{ Panel B: Loan-level variables } \\
\hline$\Delta$ Loan & -1.945 & 20.086 & 0.000 & 495,942 \\
\hline Rate & 12.51 & 5.633 & 11.642 & 188,690 \\
\hline \multicolumn{5}{|l|}{ Panel C: Firm-level variables } \\
\hline$\Delta$ Loan & -1.667 & 21.840 & -0.784 & 142,302 \\
\hline Net investment & 11.318 & 75.497 & -2.532 & 127,101 \\
\hline Wage bill growth & -1.045 & 32.162 & 1.272 & 127,621 \\
\hline
\end{tabular}




\section{Table 2: Negative Policy Rates and Bank Credit Supply—Baseline regressions}

Notes: The table presents OLS estimates of model 1. The dependent variable is loan growth at the bank-firm-month level, calculated as log difference between the post- and the pre-NIRP period. The length of the pre- and post-NIRP periods ranges between 3 and 6 months, centered around June 2014, which is excluded from the sample. Net interbank position is measured by the ratio of interbank loans minus interbank deposits with maturity up to one week, over total assets, as of end-March 2014. Liquidity is the ratio of securities over total assets, as of March 2014. Retail deposits are measured as a share of total assets, as of March 2014. TLTRO is the ratio of total loans to euro area non-financial corporations and households-excluding loans to households for house purchase- over total assets, as of April 2014. Bank control variables include: i) Size, defined as the logarithm of total assets; ii) Capital, defined as the ratio of TIER 1 capital over total assets; and iii) NPL, defined as non-performing loans scaled by total assets. These three variables are measured as of March 2014. Standard errors, double clustered at the bank and firm level, are in parentheses. ${ }^{* * *} \mathrm{p}<0.01,{ }^{* *} \mathrm{p}<0.05,{ }^{*}$ $\mathrm{p}<0.1$.

\begin{tabular}{|c|c|c|c|c|c|}
\hline Window: & \multicolumn{5}{|c|}{ \pm 3 month around June 2014} \\
\hline Net interbank position & $\begin{array}{l}0.1354^{* *} \\
(0.0585)\end{array}$ & & $\begin{array}{l}0.1176^{* *} \\
(0.0575)\end{array}$ & $\begin{array}{l}0.1148^{*} \\
(0.0582)\end{array}$ & $\begin{array}{l}0.1130^{*} \\
(0.0608)\end{array}$ \\
\hline Liquidity & & $\begin{array}{l}0.0664^{* * *} \\
(0.0194)\end{array}$ & $\begin{array}{l}0.0632^{* * *} \\
(0.0195)\end{array}$ & $\begin{array}{l}0.0712^{* * *} \\
(0.0208)\end{array}$ & $\begin{array}{l}0.0688^{* * * *} \\
(0.0224)\end{array}$ \\
\hline Retail Deposits & & & & $\begin{array}{l}0.0145 \\
(0.0209)\end{array}$ & $\begin{array}{l}0.0216 \\
(0.0241)\end{array}$ \\
\hline TLTRO & & & & & $\begin{array}{l}-0.0147 \\
(0.0305)\end{array}$ \\
\hline Observations & 495942 & 495942 & 495942 & 495942 & 495942 \\
\hline Bank controls & Yes & Yes & Yes & Yes & Yes \\
\hline Firm FE & Yes & Yes & Yes & Yes & Yes \\
\hline$R^{2}$ & 0.3679 & 0.3680 & 0.3681 & 0.3681 & 0.3681 \\
\hline Window: & \multicolumn{5}{|c|}{ \pm 6 month around June 2014} \\
\hline Net interbank position & $\begin{array}{l}0.1966^{* * *} \\
(0.0746)\end{array}$ & & $\begin{array}{l}0.1731^{* *} \\
(0.0716)\end{array}$ & $\begin{array}{l}0.1679^{* *} \\
(0.0716)\end{array}$ & $\begin{array}{l}0.1630^{* *} \\
(0.0738)\end{array}$ \\
\hline Liquidity & & $\begin{array}{l}0.0875^{* * *} \\
(0.0276)\end{array}$ & $\begin{array}{l}0.0827^{* * *} \\
(0.0270)\end{array}$ & $\begin{array}{l}0.0977^{* * *} \\
(0.0300)\end{array}$ & $\begin{array}{l}0.0908^{* * *} \\
(0.0334)\end{array}$ \\
\hline Retail Deposits & & & & $\begin{array}{l}0.0269 \\
(0.0290)\end{array}$ & $\begin{array}{l}0.0471 \\
(0.0332)\end{array}$ \\
\hline TLTRO & & & & & $\begin{array}{l}-0.0414 \\
(0.0428)\end{array}$ \\
\hline Observations & 498234 & 498234 & 498234 & 498234 & 498234 \\
\hline Bank controls & Yes & Yes & Yes & Yes & Yes \\
\hline Firm FE & Yes & Yes & Yes & Yes & Yes \\
\hline$R^{2}$ & 0.3896 & 0.3897 & 0.3898 & 0.3898 & 0.3898 \\
\hline
\end{tabular}


Table 3: Negative Policy Rates and Bank Credit Supply-Robustness

Notes: The table presents OLS estimates of model 1, with the exception of column 6, which reports the weighted least square (WLS) estimates, taking the logarithm of loan size as weight. The dependent variable is loan growth at the bank-firm-month level, calculated as log difference between the post- and the pre-NIRP period. The length of the pre- and post-NIRP periods is 3 months, centered around June 2014, which is excluded from the sample, except in column 7 (where the length of the pre- and post-NIRP periods is 12 months, centered around June 2014), and in column 9 (where the pre- and post-NIRP periods are centered around May-June 2014). Net interbank position is measured as the ratio of interbank loans minus interbank deposits with maturity up to one week, over total assets, as of end-March 2014. Liquidity is the ratio of securities over total assets, as of end-March 2014. In columns 5 the net interbank position and liquidity are measured in June 2014. Bank control variables include: i) Size, defined as the logarithm of total assets; ii) Capital, defined as the ratio of TIER 1 capital over total assets; and iii) NPL, defined as non-performing loans scaled by total assets. These three variables are measured as of March 2014 . Retail deposits are measured as a share of total assets. Secured Repo is the ratio of secured repo funding over total assets. Liabilities vis-a-vis non resident is the ratio of foreign funding (deposits from non-residents) over total assets. Securities issues is the ratio of bank-issued securities over total assets. Interbank deposits is the ratio of interbank deposits over total assets. All these variable are measured as of end-March 2014. In column 3 the sample excludes firms in the bottom half of the sample distribution of total assets, measured in March 2014. Windfall gain, included in column 4 is defined as the change in the value of securities in the marked-to-market portfolio over total equity. In column 7 the length of the pre- and post-NIRP periods is 12 months, centered around June 2014. In column 8 the pre- and post-NIRP period are computed using a \pm 3 month window around June-August 2014, which are excluded from the sample. In column 9 the pre- and post-NIRP period are computed using a \pm 3 month window around May-June 2014, which are excluded from the sample. Standard errors, double clustered at the bank and firm level, are in parentheses. ${ }^{* * *} \mathrm{p}<0.01,{ }^{* *} \mathrm{p}<0.05,{ }^{*} \mathrm{p}<0.1$.

$(1)$

$(2)$

(3)

$(4)$

(5)

(6)

(7)

(8)

(9)

Net interbank position

Net interbank position, June 2014

Liquidity

Liquidity, June 2014

Retail Deposits

Secured Repo

Liabilities vis-a-vis non-resident

Securities issued

Interbank deposits

Windfall gain

Observations
Bank controls

Firm FE

$R^{2}$

\section{$0.1210^{* *}$}

(0.0535)

$0.1178^{*}$

(0.0665)

$0.0839^{* * *} \quad 0.0757^{* * *} \quad 0.0581^{* *} \quad 0.0632^{* * *}$

$(0.0251)$

(0.0205)

(0.0233)

$0.0605^{*}$

$(0.0354)$

$-0.0446$

$(0.0682)$

$0.3288^{* *}$

(0.1285)

$0.0927^{* *}$

$(0.0381)$

0.0215

(0.0424)

$\begin{array}{ll}0.0168 & 0.0123 \\ (0.0206) & (0.0224)\end{array}$

(0.0190)

$0.1111^{*}$

$(0.0573)$

$0.2169^{* *}$

$(0.0925)$

$0.1280^{*}$

(0.0669)

$0.1599 * *$

$0.1148^{* *}$

$(0.0517)$

$0.0559^{* * *} \quad 0.0954^{* *} \quad 0.0817^{* *} \quad 0.0814^{* * *}$

$(0.0196) \quad(0.0373) \quad(0.0376)$

(0.0181)

$0.0703^{* * *}$

(0.0175)

$$
(0.0175)
$$

0.0088

(0.3050)

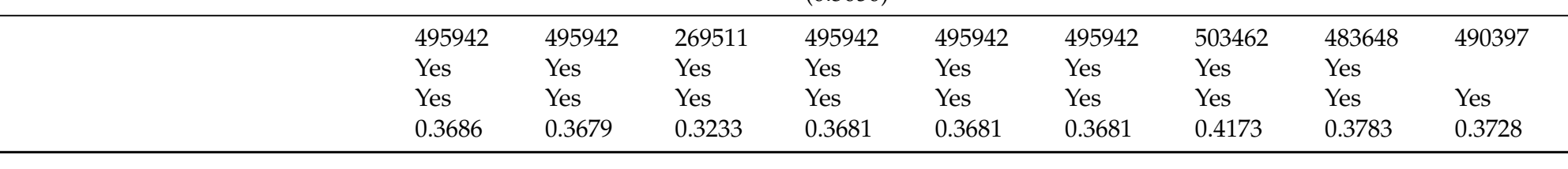




\section{Table 4: Negative Policy Rates and Bank Credit Supply_Parallel Trends}

Notes: The table presents OLS estimates of model 1. The dependent variable is loan growth at the bank-firm-month level, calculated as $\log$ difference between the post- and the pre- monetary policy announcement. In panel A, the length of the pre- and post-periods is 3 months, centered around: 1) December 2013 (columns 1-2); 2) January 2014 (columns 3-4); and February 2014 (columns 5-6). We do not expand our sample beyond February 2014 as the \pm 3 months window around March 2014 will include June 2014 (and the introduction of NIRP) in the post-period. In panel B, the length of the pre- and post-periods is 6 months, centered around: 1) September 2013 (columns 1-2); 2) October 2013 (columns 3-4); and November 2013 (columns 5-6). We do not expand our sample beyond November 2013 as the \pm 6 months window around December 2013 will include June 2014 (and the introduction of NIRP) in the post-period. In each model, the month of the policy announcement is excluded from the sample. Net interbank position in the interbank market is measured as the ratio of interbank loans minus interbank deposits with maturity up to one week, over total assets, as of end-March 2014. Liquidity is the ratio of securities over total assets as of March 2014. Bank control variables include: i) Size, defined as the logarithm of total assets; ii) Capital, defined as the ratio of TIER 1 capital over total assets; and iii) NPL, defined as non-performing loans scaled by total assets. These three variables are measured as of March 2014. Standard errors, double clustered at the bank and firm level, are in parentheses. ${ }^{* * *} \mathrm{p}<0.01,{ }^{* *} \mathrm{p}<0.05,{ }^{*} \mathrm{p}<0.1$.

\section{(1)}

(2)

(3)

Panel A: \pm 3 months windows

\begin{tabular}{|c|c|c|c|}
\hline & Sep 2013-Mar 2014 & Oct 2013-Apr 2014 & Nov 2013-May 2014 \\
\hline Net interbank position & $\begin{array}{l}-0.0083 \\
(0.0449)\end{array}$ & $\begin{array}{l}0.0187 \\
(0.0503)\end{array}$ & $\begin{array}{l}0.0556 \\
(0.0512)\end{array}$ \\
\hline Liquidity & $\begin{array}{l}-0.0847^{* * *} \\
(0.0282)\end{array}$ & $\begin{array}{l}-0.0542 \\
(0.0357)\end{array}$ & $\begin{array}{l}-0.0052 \\
(0.0280)\end{array}$ \\
\hline Observations & 508784 & 506734 & 507318 \\
\hline$R^{2}$ & 0.3717 & 0.3698 & 0.3684 \\
\hline
\end{tabular}

Panel B: \pm 6 months windows

\begin{tabular}{|c|c|c|c|}
\hline & Mar 2013-Mar 2014 & Apr 2013-Apr 2014 & May 2013-May 2014 \\
\hline $\begin{array}{l}\text { Net interbank position } \\
\text { Liquidity }\end{array}$ & $\begin{array}{l}0.0173 \\
(0.0786) \\
0.0189 \\
(0.0201)\end{array}$ & $\begin{array}{l}0.0263 \\
(0.0699) \\
-0.0008 \\
(0.0196)\end{array}$ & $\begin{array}{l}0.0545 \\
(0.0677) \\
-0.0229 \\
(0.0238)\end{array}$ \\
\hline $\begin{array}{l}\text { Observations } \\
\text { Firm FE } \\
\text { Bank controls } \\
R^{2}\end{array}$ & $\begin{array}{l}522720 \\
\text { Yes } \\
\text { Yes } \\
0.3910\end{array}$ & $\begin{array}{l}518876 \\
\text { Yes } \\
\text { Yes } \\
0.3914\end{array}$ & $\begin{array}{l}514457 \\
\text { Yes } \\
\text { Yes } \\
0.3909\end{array}$ \\
\hline
\end{tabular}


Table 5: Other Monetary Policy Announcements and Bank Credit Supply

Notes: The table presents OLS estimates of model 1. The dependent variable is loan growth at the bank-firm-month level, calculated as $\log$ difference between the post- and the pre- monetary policy announcement. The length of the pre- and post-periods is 3 (Panel A) and 6 (Panel B) months, centered around: 1) July 2012, the latest rate cut in positive territory (column 1); 2) July 2013, the first forward guidance announcement (column 2); and 3) January 2015, the announcement of QE (expanded asset purchase programme) (column 3). In each model, the month of the policy announcement is excluded from the sample. Net interbank position in the interbank market is measured as the ratio of interbank loans minus interbank deposits with maturity up to one week, over total assets, as of June 2012 (column 1), June 2013 (column 2), and December 2014 (column 3). Liquidity is the ratio of securities over total assets, as of June 2012 (column 1), June 2013 (column 2), and December 2014 (column 3). Bank control variables include: i) Size, defined as the logarithm of total assets; ii) Capital, defined as the ratio of TIER 1 capital over total assets; and iii) NPL, defined as non-performing loans scaled by total assets. These three variables are measured as of June 2012 (column 1), June 2013 (column 2), and December 2014 (column 3 ). Standard errors, double clustered at the bank and firm level, are in parentheses. ${ }^{* * *} \mathrm{p}<0.01,{ }^{* *} \mathrm{p}<0.05,{ }^{*} \mathrm{p}<0.1$.

Panel A: \pm 3 months window around:

\begin{tabular}{llll}
\hline $\begin{array}{l}\text { Previous Rate Cut } \\
\text { (July 2012) }\end{array}$ & & $\begin{array}{l}\text { Forward Guidance } \\
\text { (July 2013) }\end{array}$ & $\begin{array}{l}\text { QE (APP) } \\
\text { (January 2015) }\end{array}$ \\
\cline { 1 - 1 }$-0.2042^{* * *}$ & & $-0.1188^{*}$ & 0.0713 \\
$(0.0548)$ & $(0.0622)$ & $(0.0548)$ \\
$-0.0701^{*}$ & $0.0420^{* *}$ & $0.0779^{* * *}$ \\
$(0.0396)$ & $(0.0186)$ & $(0.0183)$ \\
560352 & 527335 & \\
0.3699 & 0.3704 & 479977 \\
& & 0.3612 \\
\hline
\end{tabular}

Net interbank position

Liquidity

Observations

$R^{2}$

$+2$

Net interbank position

Liquidity
Panel B: \pm 6 months window around:

\begin{tabular}{|c|c|c|}
\hline $\begin{array}{l}\text { Previous Rate Cut } \\
\text { (July 2012) }\end{array}$ & $\begin{array}{l}\text { Forward Guidance } \\
\text { (July 2013) }\end{array}$ & $\begin{array}{l}\text { QE (APP) } \\
\text { (January 2015) }\end{array}$ \\
\hline $\begin{array}{l}-0.2709^{* * *} \\
(0.0715) \\
-0.1046^{*} \\
(0.0532)\end{array}$ & $\begin{array}{l}-0.0989 \\
(0.1359) \\
0.0146 \\
(0.0286)\end{array}$ & $\begin{array}{l}0.1291 \\
(0.0812) \\
0.1248^{* * *} \\
(0.0348)\end{array}$ \\
\hline $\begin{array}{l}562857 \\
\text { Yes } \\
\text { Yes } \\
0.3856\end{array}$ & $\begin{array}{l}529914 \\
\text { Yes } \\
\text { Yes } \\
0.3897\end{array}$ & $\begin{array}{l}481942 \\
\text { Yes } \\
\text { Yes } \\
0.3802\end{array}$ \\
\hline
\end{tabular}




\section{Table 6: Negative Policy Rates and Bank Credit Supply—Firm Heterogeneity}

Notes: The table presents OLS estimates of model 1. The dependent variable is loan growth at the bank-firm-month level, calculated as log difference between the post-and the pre-NIRP period. The length of the pre- and post-NIRP period ranges between 3 (first three columns) and 6 (last three columns) months, centered around June 2014, which is excluded from the sample. Panel A looks at the heterogeneous effects of net interbank position across firm's rating and size. Panel B replicates this analysis cosnidering the heterogeneous effects of liquidity. Net interbank position is measured as the ratio of interbank loans minus interbank deposits with maturity up to one week, over total assets, as of end-March 2014. The standalone net interbank position and other bank controls-liquidity, capital, size and NPL, as in the baseline (Table 2) - are absorbed by the bank fixed effects, as they are time-invariant (measured as of end-March 2014). Risky firms are defined as those above the median of the Altman z-score, measured on a scale from 1 to $9,1=$ best, $9=$ worst. Small firms are defined as below the median of total assets. All these splits are done using data as of March 2014. Standard errors, double clustered at the bank and firm level, are in parentheses. ${ }^{* * *} \mathrm{p}<0.01,{ }^{* *} \mathrm{p}<0.05,{ }^{*} \mathrm{p}<0.1$.

\begin{tabular}{|c|c|c|c|c|c|c|}
\hline \multirow{2}{*}{$\begin{array}{l}\text { Window: } \\
\text { Panel A: Net interbank position }\end{array}$} & \multicolumn{3}{|c|}{ \pm 3 month around June 2014} & \multicolumn{3}{|c|}{ \pm 6 months around June 2014} \\
\hline & & & & & & \\
\hline Net interbank position $\mathrm{x}$ risky & $\begin{array}{l}0.1609 * * \\
(0.0778)\end{array}$ & & $\begin{array}{l}0.1544^{*} \\
(0.0780)\end{array}$ & $\begin{array}{l}0.1815 \\
(0.1296)\end{array}$ & & $\begin{array}{l}0.1721 \\
(0.1305)\end{array}$ \\
\hline Net interbank position $\mathrm{x}$ small & & $\begin{array}{l}0.1082^{* *} \\
(0.0532)\end{array}$ & $\begin{array}{l}0.0975^{*} \\
(0.0529)\end{array}$ & & $\begin{array}{l}0.1698^{* *} \\
(0.0704)\end{array}$ & $\begin{array}{l}0.1532^{* *} \\
(0.0706)\end{array}$ \\
\hline $\begin{array}{l}\text { Observations } \\
\text { Firm FE } \\
\text { Bank FE } \\
R^{2}\end{array}$ & $\begin{array}{l}439039 \\
\text { Yes } \\
\text { Yes } \\
0.3629\end{array}$ & $\begin{array}{l}441144 \\
\text { Yes } \\
\text { Yes } \\
0.3635\end{array}$ & $\begin{array}{l}439029 \\
\text { Yes } \\
\text { Yes } \\
0.3629\end{array}$ & $\begin{array}{l}440882 \\
\text { Yes } \\
\text { Yes } \\
0.3845\end{array}$ & $\begin{array}{l}442992 \\
\text { Yes } \\
\text { Yes } \\
0.3851\end{array}$ & $\begin{array}{l}440840 \\
\text { Yes } \\
\text { Yes } \\
0.3845\end{array}$ \\
\hline \multicolumn{7}{|l|}{ Panel B: Liquidity } \\
\hline Liquidity $\mathrm{x}$ risky & $\begin{array}{l}0.0730^{* * *} \\
(0.0272)\end{array}$ & & $\begin{array}{l}0.0690^{* *} \\
(0.0275)\end{array}$ & $\begin{array}{l}0.1370^{* * *} \\
(0.0393)\end{array}$ & & $\begin{array}{l}0.1352^{* * * *} \\
(0.0399)\end{array}$ \\
\hline Liquidity $x$ small & & $\begin{array}{l}0.0564^{* * *} \\
(0.0184)\end{array}$ & $\begin{array}{l}0.0511^{* * *} \\
(0.0185)\end{array}$ & & $\begin{array}{l}0.0404 \\
(0.0271)\end{array}$ & $\begin{array}{l}0.0299 \\
(0.0276)\end{array}$ \\
\hline Observations & 439039 & 441144 & 439029 & 440882 & 442992 & 440840 \\
\hline Firm FE & Yes & Yes & Yes & Yes & Yes & Yes \\
\hline Bank FE & Yes & Yes & Yes & Yes & Yes & Yes \\
\hline$R^{2}$ & 0.3630 & 0.3635 & 0.3630 & 0.3847 & 0.3851 & 0.3846 \\
\hline
\end{tabular}




\section{Table 7: Negative Policy Rates and Lending Rates}

Notes: The table presents OLS estimates of model 1. The dependent variable is the change in lending rates at the bank-firm-month level, calculated as difference between the post- and the pre-NIRP period. Lending rates are gross rates including commissions and fees. The length of the pre- and post-NIRP period is of 6 months, centered around June 2014, which is excluded from the sample. Net interbank position is measured as the ratio of interbank loans minus interbank deposits with maturity up to one week, over total assets, as of end-March 2014. Liquidity is the ratio of securities over total assets as of March 2014. Retail deposits are measured as a share of total assets, as of March 2014. TLTRO is the ratio of total loans to euro area non-financial corporations and households-excluding loans to households for house purchase-over total assets, as of April 2014. Bank control variables include: i) Size, defined as the logarithm of total assets; ii) Capital, defined as the ratio of TIER 1 capital over total assets; and iii) NPL, defined as non-performing loans scaled by total assets. These three variables are measured as of March 2014. Standard errors, double clustered at the bank and firm level, are in parentheses. ${ }^{* *} \mathrm{p}<0.01,{ }^{* *} \mathrm{p}<0.05,{ }^{*} \mathrm{p}<0.1$.

\begin{tabular}{|c|c|c|c|c|c|}
\hline & $(1)$ & $(2)$ & (3) & (4) & (5) \\
\hline Net interbank position & $\begin{array}{l}-0.0996^{* * *} \\
(0.0282)\end{array}$ & & $\begin{array}{l}-0.0842^{* * *} \\
(0.0159)\end{array}$ & $\begin{array}{l}-0.0846^{* * *} \\
(0.0169)\end{array}$ & $\begin{array}{l}-0.0806^{* * *} \\
(0.0188)\end{array}$ \\
\hline Liquidity & & $\begin{array}{l}-0.0452^{* * *} \\
(0.0132)\end{array}$ & $\begin{array}{l}-0.0427^{* * *} \\
(0.0118)\end{array}$ & $\begin{array}{l}-0.0423^{* * *} \\
(0.0139)\end{array}$ & $\begin{array}{l}-0.0402^{* * * *} \\
(0.0135)\end{array}$ \\
\hline Retail Deposits & & & & $\begin{array}{l}0.0007 \\
(0.0054)\end{array}$ & $\begin{array}{l}-0.0069 \\
(0.0058)\end{array}$ \\
\hline TLTRO & & & & & $\begin{array}{l}0.0180^{* *} \\
(0.0083)\end{array}$ \\
\hline Observations & 188690 & 188690 & 188690 & 188690 & 188690 \\
\hline Bank controls & Yes & Yes & Yes & Yes & Yes \\
\hline Firm FE & Yes & Yes & Yes & Yes & Yes \\
\hline$R^{2}$ & 0.3959 & 0.3973 & 0.3979 & 0.3979 & 0.3981 \\
\hline
\end{tabular}




\section{Table 8: Negative Policy Rates, Firm-level Credit Supply and Real Effects}

Notes: The table presents OLS estimates of model 2. The dependent variable is, alternatively: 1) loan growth at the firm-month level, calculated as log difference between the 6-month post- and the 6-month pre-NIRP period, 2) net investment, defined as the growth rate of fixed assets between 2014 and 2013; and 3) the growth rate of the wage bill between 2014 and 2013. All other control variables are firm-level averages of bank characteristics, weighted by the share of total credit granted to the firm by each bank, as of March 2014. Net interbank position is measured as the ratio of interbank loans minus interbank deposits with maturity up to one week, over total assets, as of end-March 2014. Liquidity is the ratio of securities over total assets as of March 2014. Credit demand is a vector of estimates of firm credit demand obtained from the baseline within firm model (Table 2, column 1). Firm-level bank control variables include: i) Size, defined as the logarithm of total assets; ii) Capital, defined as the ratio of TIER 1 capital over total assets; and iii) NPL, defined as non-performing loans scaled by total assets. These three variables are measured as of March 2014. The sample includes manufacturing firms (Panel A) or all firms (Panel B). Standard errors, clustered at the main bank level, are in parentheses. ${ }^{* * *} \mathrm{p}<0.01$, ${ }^{* *} \mathrm{p}<0.05,{ }^{*} \mathrm{p}<0.1$.

\begin{tabular}{|c|c|c|c|}
\hline & \multicolumn{3}{|c|}{ Panel A: Manufacturing firms } \\
\hline & $\begin{array}{l}\text { Loan growth } \\
\text { (1) }\end{array}$ & $\begin{array}{l}\text { Net investment } \\
(2)\end{array}$ & $\begin{array}{l}\text { Wage bill growth } \\
\text { (3) }\end{array}$ \\
\hline Net interbank exposure & $\begin{array}{l}0.3258^{* * *} \\
(0.0873)\end{array}$ & $\begin{array}{l}0.5228^{*} \\
(0.2654)\end{array}$ & $\begin{array}{l}0.3239^{* * *} \\
(0.1213)\end{array}$ \\
\hline Liquidity & $\begin{array}{l}0.0903^{* * *} \\
(0.0224)\end{array}$ & $\begin{array}{l}0.3679^{* * *} \\
(0.0780)\end{array}$ & $\begin{array}{l}0.0256 \\
(0.0278)\end{array}$ \\
\hline Credit demand & $\begin{array}{l}0.9833^{* * *} \\
(0.0051)\end{array}$ & $\begin{array}{l}0.4950 * * * \\
(0.0328)\end{array}$ & $\begin{array}{l}0.2655^{* * *} \\
(0.0092)\end{array}$ \\
\hline Observations & 49831 & 48257 & 47428 \\
\hline Firm-level bank controls & Yes & Yes & Yes \\
\hline Industry FE & Yes & Yes & Yes \\
\hline Province FE & Yes & Yes & Yes \\
\hline \multirow[t]{3}{*}{$R^{2}$} & 0.6231 & 0.0298 & 0.0551 \\
\hline & \multicolumn{3}{|c|}{ Panel B: All firms } \\
\hline & $\begin{array}{l}\text { Loan growth } \\
\text { (4) }\end{array}$ & $\begin{array}{l}\text { Net investment } \\
\text { (5) }\end{array}$ & $\begin{array}{l}\text { Wage bill growth } \\
\text { (6) }\end{array}$ \\
\hline Net interbank exposure & $\begin{array}{l}0.2627^{* * *} \\
(0.0408)\end{array}$ & $\begin{array}{l}0.0433 \\
(0.2692)\end{array}$ & $\begin{array}{l}0.3157^{* * *} \\
(0.1150)\end{array}$ \\
\hline Liquidity & $\begin{array}{l}0.1013^{* * *} \\
(0.0199)\end{array}$ & $\begin{array}{l}0.2193^{* * *} \\
(0.0681)\end{array}$ & $\begin{array}{l}0.0245 \\
(0.0324)\end{array}$ \\
\hline Credit demand & $\begin{array}{l}1.0090^{* * *} \\
(0.0024)\end{array}$ & $\begin{array}{l}0.4985^{* * *} \\
(0.0118)\end{array}$ & $\begin{array}{l}0.3173^{* * *} \\
(0.0111)\end{array}$ \\
\hline Observations & 142302 & 134960 & 127621 \\
\hline Firm-level bank controls & Yes & Yes & Yes \\
\hline Industry FE & Yes & Yes & Yes \\
\hline Province FE & Yes & Yes & Yes \\
\hline$R^{2}$ & 0.6080 & 0.0242 & 0.0554 \\
\hline
\end{tabular}




\section{A Online Appendix-Not for publication}

\section{Additional Figures}

Figure A1: Net Interbank Position and Liquidity in December 2013 and March 2014

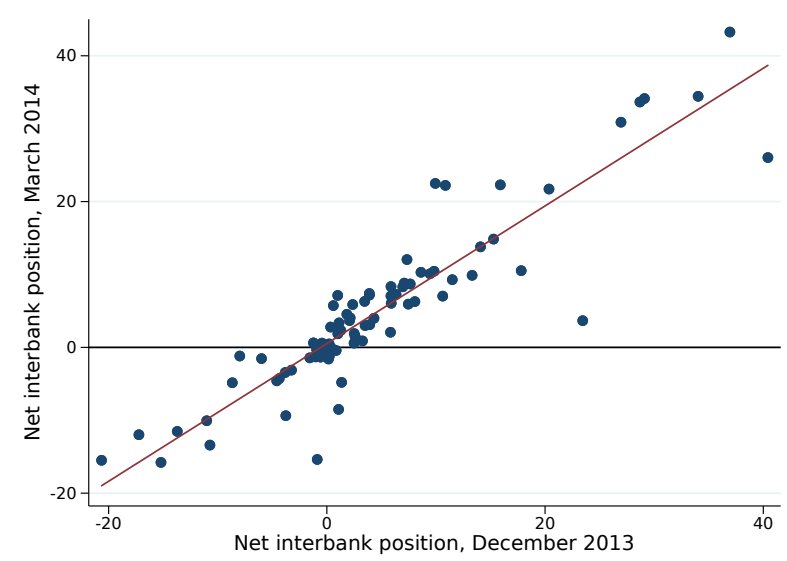

(a) Net interbank position

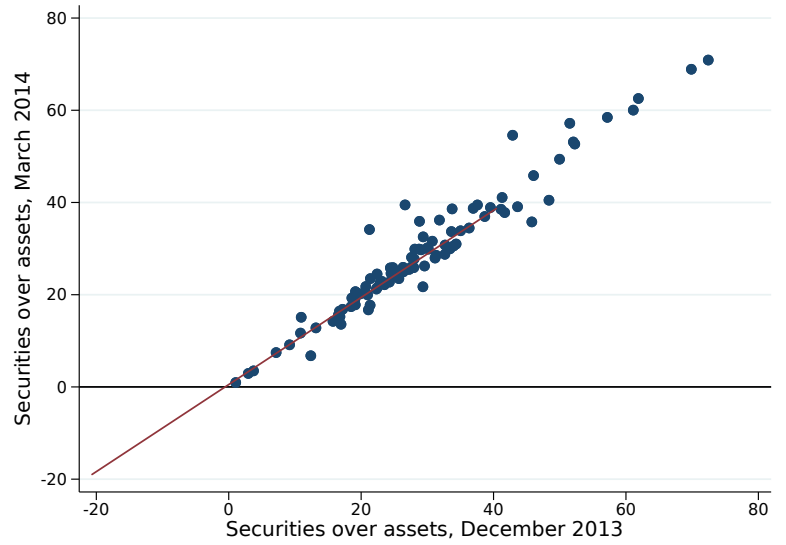

(b) Liquidity

Notes: The chart plots the correlation between the net interbank positions (calculated as the ratio of interbank loans minus interbank deposits with maturity up to one week, in percent of total assets) and liquidity (calculated as the ratio of securities over total assets, in percent) measured in December 2013 and March 2014. The variables are winsorized at the $1^{\text {st }}$ and $99^{\text {th }}$ percentiles. Source: Bank of Italy. 
Figure A2: Net Interbank Position and Liquidity

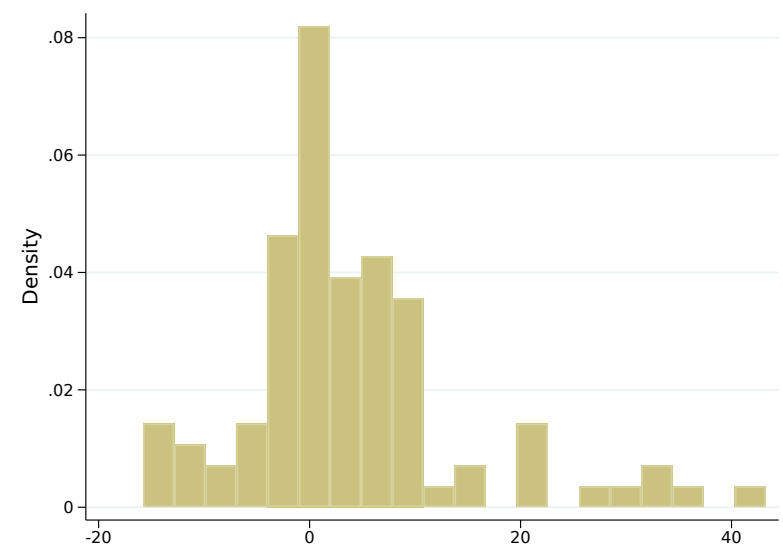

(a) Net interbank position

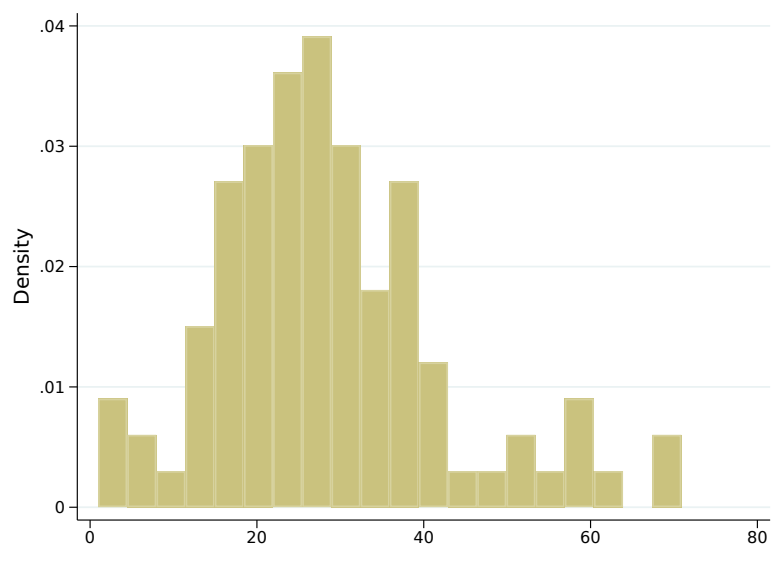

(b) Liquidity

Notes: The chart plots the distribution of: i) the net interbank position, measured as interbank loans minus interbank deposits with maturity of up to one week, as a percentage of total assets (panel a); and ii) liquidity, measured as securities in percent of total assets (panel b). Both variables are measured as of March 2014 and are winsorized at the $1^{\text {st }}$ and $99^{\text {th }}$ percentiles. The sample includes 95 banks. Source: Bank of Italy. 


\section{Additional Tables}

\section{Table A1: Negative Policy Rates and Fee Income}

Notes: The table shows OLS estimates of a bank-level cross sectional regression. The dependent variable is the change in banks' income from fees over the 6 months following the introduction of NIRP, June-December 2014 (data on income from fees is available every six months). Retail deposits are measured as a share of total assets, as of end-March 2014. Bank control variables include: i) Net interbank position, defined as the ratio of interbank loans minus interbank deposits with maturity up to one week, over total assets; ii) Liquidity, defined as the ratio of securities over total assets; iii) Size, defined as the logarithm of total assets; iv) Capital, defined as the ratio of TIER 1 capital over total assets; and v) NPL, defined as non-performing loans scaled by total assets. Also the control variables are measured before the announcement of NIRP. Data on income from fees are missing for 12 banks in our baseline sample. If we assume that these banks have no income from fees, results on the full sample of 95 banks do not change (e.g., the point estimates and significance level are almost identical). Robust standard errors in parentheses. ${ }^{* *} \mathrm{p}<0.01,{ }^{* *} \mathrm{p}<0.05,{ }^{*} \mathrm{p}<0.1$.

$(1)$

$0.0031^{* * *}$

$(0.0007)$

83

No

0.2111
(2)

$0.0023^{* * *}$

(0.0007)

83

Yes

0.4119

$R^{2}$ 


\section{Table A2: Negative Policy Rates, Net Interbank Position and Liquidity}

Notes: The table shows OLS estimates of a bank-level cross sectional regression. The dependent variable measures the change between March and September 2014 of banks': 1) net interbank position (column 1); 2) interbank loans with maturity up to one week over assets (column2); 3) interbank deposits with maturity up to one week over assets (column 3); and liquidity, measured as the ratio of securities over total assets (column 4). Net interbank position is measured as the ratio of interbank loans minus interbank deposits with maturity up to one week, over total assets, as of end-March 2014. Liquidity is the ratio of securities over total assets, as of March 2014. Bank control variables include: i) Size, defined as the logarithm of total assets; ii) Capital, defined as the ratio of TIER 1 capital over total assets; and iii) NPL, defined as non-performing loans scaled by total assets. These three variables are measured as of March 2014. Robust standard errors in parentheses. ${ }^{* * *} \mathrm{p}<0.01,{ }^{* *} \mathrm{p}<0.05,{ }^{*} \mathrm{p}<0.1$.

\begin{tabular}{|c|c|c|c|c|}
\hline & $\begin{array}{l}\Delta \text { net interbank } \\
\text { position } \\
\text { (1) }\end{array}$ & $\begin{array}{l}\Delta \text { interbank loans } \\
\text { (2) }\end{array}$ & $\begin{array}{l}\Delta \text { interbank de- } \\
\text { posits } \\
\text { (3) }\end{array}$ & $\begin{array}{l}\Delta \text { liquidity } \\
\text { (4) }\end{array}$ \\
\hline $\begin{array}{l}\text { Net interbank position } \\
\text { Liquidity }\end{array}$ & $\begin{array}{l}-0.2180^{* *} \\
(0.0851) \\
-0.0398 \\
(0.0407)\end{array}$ & $\begin{array}{l}-0.1644^{* *} \\
(0.0741) \\
-0.0080 \\
(0.0369)\end{array}$ & $\begin{array}{l}0.0536 \\
(0.0545) \\
0.0318 \\
(0.0214)\end{array}$ & $\begin{array}{l}0.0530 \\
(0.0501) \\
-0.1016^{* *} \\
(0.0394)\end{array}$ \\
\hline $\begin{array}{l}\text { Observations } \\
\text { Bank controls } \\
R^{2}\end{array}$ & $\begin{array}{l}95 \\
\text { Yes } \\
0.1985\end{array}$ & $\begin{array}{l}95 \\
\text { Yes } \\
0.1643\end{array}$ & $\begin{array}{l}95 \\
\text { Yes } \\
0.0338\end{array}$ & $\begin{array}{l}95 \\
\text { Yes } \\
0.1509\end{array}$ \\
\hline
\end{tabular}




\section{Table A3: Negative Policy Rates, Net Interbank Position and Liquidity, Placebo}

Notes: The table shows OLS estimates of a bank-level cross sectional regression. The dependent variable measures the change between September 2013 and March 2014 of banks': 1) net interbank position (column 1); 2) interbank loans with maturity up to one week over assets (column2);3) interbank deposits with maturity up to one week over assets (column 3); and liquidity, measured as the ratio of securities over total assets (column 4). Net interbank position is measured as the ratio of interbank loans minus interbank deposits with maturity up to one week, over total assets, as of end-September 2013. Liquidity is the ratio of securities over total assets, as of September 2013. Bank control variables include: i) Size, defined as the logarithm of total assets; ii) Capital, defined as the ratio of TIER 1 capital over total assets; and iii) NPL, defined as non-performing loans scaled by total assets. These three variables are measured as of September 2013. Robust standard errors in parentheses. ${ }^{* * *} \mathrm{p}<0.01,{ }^{* *} \mathrm{p}<0.05,{ }^{*} \mathrm{p}<0.1$.

\begin{tabular}{lllll}
\hline & $\begin{array}{l}\Delta \text { net interbank } \\
\text { position } \\
(1)\end{array}$ & $\Delta$ interbank loans & $\begin{array}{l}\Delta \text { interbank de- } \\
\text { posits } \\
(3)\end{array}$ & $\Delta$ liquidity \\
\cline { 2 - 5 } & & $(2)$ & & $(4)$ \\
Net interbank position & $-0.1306^{*}$ & -0.0594 & 0.0712 & 0.0348 \\
Liquidity & $(0.0775)$ & $(0.0772)$ & $(0.0469)$ & $(0.0887)$ \\
& 0.0433 & 0.0491 & 0.0058 & -0.0489 \\
& $(0.0372)$ & $(0.0358)$ & $(0.0211)$ & $(0.0469)$ \\
\hline Observations & 95 & & 95 & 95 \\
Bank controls & Yes & 95 & Yes & Yes \\
$R^{2}$ & 0.1850 & Yes & 0.1508 & 0.0964 \\
\hline
\end{tabular}




\section{Table A4: Net interbank position, Liquidity, and Bank Characteristics}

Notes: The table shows OLS estimates of a bank-level cross sectional regression. The dependent variable is, alternatively, the net interbank position (column 1) and liquidity (column 2). The net interbank position is measured as the ratio of interbank loans minus interbank deposits with maturity up to one week, over total assets, as of end-March 2014. Liquidity is the ratio of securities over total assets, as of March 2014. Bank control variables include: i) Size, defined as the logarithm of total assets; ii) Capital, defined as the ratio of TIER 1 capital over total assets; and iii) NPL, defined as non-performing loans scaled by total assets. These three variables are measured as of June 2014. Robust standard errors in parentheses. ${ }^{* * *} \mathrm{p}<0.01,{ }^{* *} \mathrm{p}<0.05,{ }^{*} \mathrm{p}<0.1$.

\begin{tabular}{|c|c|c|}
\hline & $\begin{array}{l}\text { Net interbank position } \\
\text { (1) }\end{array}$ & $\begin{array}{l}\text { Liquidity } \\
\text { (2) }\end{array}$ \\
\hline Size & $\begin{array}{l}-2.2878^{* * *} \\
(0.4614)\end{array}$ & $\begin{array}{l}-0.3338 \\
(0.5773)\end{array}$ \\
\hline Capital & $\begin{array}{l}0.2630 \\
(0.2178)\end{array}$ & $\begin{array}{l}-0.8104^{* * *} \\
(0.2526)\end{array}$ \\
\hline NPL & $\begin{array}{l}0.0725 \\
(0.3030)\end{array}$ & $\begin{array}{l}-1.8584^{* * * *} \\
(0.3580)\end{array}$ \\
\hline Observations & 95 & 95 \\
\hline$R^{2}$ & 0.3340 & 0.2425 \\
\hline
\end{tabular}


Table A5: Balancing of Observable Firm Characteristics

Notes: The table report, for each variable, the average values computed by quartile of bank exposure to NIRP, considering the net interbank position (Panel A) or liquidity (Panel B). Net interbank position is measured as the ratio of interbank loans minus interbank deposits with maturity up to one week, over total assets. Liquidity is the ratio of securities over total assets. Figures in parentheses are the normalized differences (the difference between the quartile average and the average of the other three quartiles, normalized by the square root of the sum of the corresponding variances). Imbens and Wooldridge (2009) propose as a rule of thumb a 0.25 threshold in absolute terms, i.e. two variables have "similar" means when the normalized difference does not exceed one quarter. Firm size is the $\log$ of firm's assets; Z-score is the Altman Z-score (Altman, 1968) as computed by CERVED; Equity / Debt is the ratio of the book value of equity to firm's debt; Profitability is the ratio of earnings before interest taxes, depreciation and amortization (EBITDA) to firm's assets.

\begin{tabular}{|c|c|c|c|c|}
\hline & $1^{\text {st }}$ Quartile & $2^{\text {nd }}$ Quartile & $3^{r d}$ Quartile & $4^{\text {th }}$ Quartile \\
\hline & \multicolumn{4}{|c|}{ Panel A. Net interbank position } \\
\hline Firm size & $\begin{array}{l}7.639 \\
(0.004)\end{array}$ & $\begin{array}{l}7.721 \\
(0.071)\end{array}$ & $\begin{array}{l}7.547 \\
(-0.075)\end{array}$ & $\begin{array}{l}7.642 \\
(0.006)\end{array}$ \\
\hline Z-score & $\begin{array}{l}5.118 \\
(-0.048)\end{array}$ & $\begin{array}{l}5.188 \\
(0.001)\end{array}$ & $\begin{array}{l}5.142 \\
(-0.031)\end{array}$ & $\begin{array}{l}5.315 \\
(0.086)\end{array}$ \\
\hline Equity/Debt & $\begin{array}{l}0.528 \\
(0.053)\end{array}$ & $\begin{array}{l}0.487 \\
(-0.009)\end{array}$ & $\begin{array}{l}0.498 \\
(0.008)\end{array}$ & $\begin{array}{l}0.453 \\
(-0.060)\end{array}$ \\
\hline \multirow[t]{2}{*}{ Profitability } & $\begin{array}{l}5.959 \\
(0.005)\end{array}$ & $\begin{array}{l}5.726 \\
(-0.020)\end{array}$ & $\begin{array}{l}6.144 \\
(0.026)\end{array}$ & $\begin{array}{l}5.792 \\
(-0.013)\end{array}$ \\
\hline & \multicolumn{4}{|c|}{ Panel B. Liquidity } \\
\hline Firm size & $\begin{array}{l}7.602 \\
(0.021)\end{array}$ & $\begin{array}{l}7.681 \\
(0.064)\end{array}$ & $\begin{array}{l}7.568 \\
(0.070)\end{array}$ & $\begin{array}{l}7.723 \\
(0.057)\end{array}$ \\
\hline Z-score & $\begin{array}{l}5.375 \\
(0.102)\end{array}$ & $\begin{array}{l}5.113 \\
(0.081)\end{array}$ & $\begin{array}{l}5.256 \\
(0.060)\end{array}$ & $\begin{array}{l}5.346 \\
(0.086)\end{array}$ \\
\hline Equity/Debt & $\begin{array}{l}0.425 \\
(0.083)\end{array}$ & $\begin{array}{l}0.521 \\
(0.069)\end{array}$ & $\begin{array}{l}0.464 \\
(0.054)\end{array}$ & $\begin{array}{l}0.445 \\
(0.057)\end{array}$ \\
\hline Profitability & $\begin{array}{l}5.443 \\
(0.041)\end{array}$ & $\begin{array}{l}5.924 \\
(0.002)\end{array}$ & $\begin{array}{l}5.958 \\
(0.006)\end{array}$ & $\begin{array}{l}5.698 \\
(0.0190)\end{array}$ \\
\hline
\end{tabular}




\section{Table A6: Baseline regressions-Negative Policy Rates and Bank Credit Supply, 1-month Window}

Notes: The table presents OLS estimates of model 1. The dependent variable is loan growth at the bank-firm-month level, calculated as log difference between the July 2014 (the post-NIRP period) and April 2014 (the pre-NIRP period). May and June 2014 are excluded from the sample. Net interbank position is measured by the ratio of interbank loans minus interbank deposits with maturity up to one week, over total assets, as of end-March 2014. Liquidity is the ratio of securities over total assets, as of March 2014. Retail deposits are measured as a share of total assets, as of March 2014. TLTRO is the ratio of total loans to euro area non-financial corporations and households-excluding loans to households for house purchase-over total assets, as of April 2014. Bank control variables include: i) Size, defined as the logarithm of total assets; ii) Capital, defined as the ratio of TIER 1 capital over total assets; and iii) NPL, defined as non-performing loans scaled by total assets. These three variables are measured as of March 2014. Standard errors, double clustered at the bank and firm level, are in parentheses. ${ }^{* * *} \mathrm{p}<0.01,{ }^{* *} \mathrm{p}<0.05,{ }^{*} \mathrm{p}<0.1$.

\begin{tabular}{|c|c|c|c|c|c|}
\hline \multirow{2}{*}{ Window: } & (1) & $(2)$ & (3) & (4) & (5) \\
\hline & \multicolumn{5}{|c|}{ \pm 1 month around May-June 2014} \\
\hline Net interbank position & $\begin{array}{l}0.1083^{* *} \\
(0.0512)\end{array}$ & & $\begin{array}{l}0.0992^{*} \\
(0.0510)\end{array}$ & $\begin{array}{l}0.0987^{*} \\
(0.0523)\end{array}$ & $\begin{array}{l}0.0973^{*} \\
(0.0545)\end{array}$ \\
\hline Liquidity & & $\begin{array}{l}0.0356^{* * *} \\
(0.0112)\end{array}$ & $\begin{array}{l}0.0329^{* * *} \\
(0.0110)\end{array}$ & $\begin{array}{l}0.0343^{* *} \\
(0.0133)\end{array}$ & $\begin{array}{l}0.0323^{* * *} \\
(0.0132)\end{array}$ \\
\hline Retail Deposits & & & & $\begin{array}{l}0.0025 \\
(0.0145)\end{array}$ & $\begin{array}{l}0.0084 \\
(0.0206)\end{array}$ \\
\hline TLTRO & & & & & $\begin{array}{l}-0.0121 \\
(0.0245)\end{array}$ \\
\hline Observations & 487882 & 487882 & 487882 & 487882 & 487882 \\
\hline Firm FE & Yes & Yes & Yes & Yes & Yes \\
\hline$R^{2}$ & 0.3553 & 0.3553 & 0.3554 & 0.3554 & 0.3554 \\
\hline
\end{tabular}




\section{Table A7: Negative Policy Rates and Non-Performing Loans}

Notes: The table shows OLS estimates of a bank-level cross sectional regression. The dependent variable is the change in banks' nonperforming loans (NPL) scaled by total assets over the 12 months period following the introduction of NIRP, March 2014-March 2015.. Net interbank position is measured as the ratio of interbank loans minus interbank deposits with maturity up to one week, over total assets, as of end-March 2014. Liquidity is the ratio of securities over total assets, as of March 2014. Bank control variables include: i) Size, defined as the logarithm of total assets; ii) Capital, defined as the ratio of TIER 1 capital over total assets; and iii) NPL, defined as non-performing loans scaled by total assets. These three variables are measured as of March 2014. Data on the change in banks' non-performing loans is missing for 1 bank in our baseline sample, as the bank is not operative in March 2015. Robust standard errors in parentheses. ${ }^{* * *} \mathrm{p}<0.01,{ }^{* *} \mathrm{p}<0.05,{ }^{*} \mathrm{p}<0.1$.

$(1)$

$-0.0133$

$(0.0116)$

Liquidity
(2)

$\begin{array}{ll} & -0.0101 \\ & (0.0242) \\ -0.0213 & 0.0102 \\ (0.0132) & (0.0138)\end{array}$

\begin{tabular}{llll}
\hline Observations & 94 & 94 & 94 \\
Bank controls & No & No & Yes \\
$R^{2}$ & 0.0062 & 0.0260 & 0.4067
\end{tabular}

